Research Article

\title{
Experimental Behavior of Concrete-Filled Steel Tubular Members Subjected to Lateral Loads
}

\author{
Chengzhi Wang $\mathbb{D}^{\mathrm{D}}$, Xin Liu, and Pengfei Li $\mathbb{1}$ \\ Chongqing Jiaotong University, Chongqing 400074, China \\ Correspondence should be addressed to Chengzhi Wang; wangcz@cqjtu.edu.cn
}

Received 28 November 2017; Revised 21 March 2018; Accepted 31 March 2018; Published 8 May 2018

Academic Editor: Enzo Martinelli

Copyright (c) 2018 Chengzhi Wang et al. This is an open access article distributed under the Creative Commons Attribution License, which permits unrestricted use, distribution, and reproduction in any medium, provided the original work is properly cited.

\begin{abstract}
The findings of an experimental study that was undertaken to investigate the performance of concrete-filled steel tubular members subjected to lateral loads are reported in this study. Columns of pure concrete, concrete with reinforcing bars, and two steel tube thicknesses were considered. Two different tests were conducted in this study. One test is used to research the performance of steel tube-reinforced concrete model piles under a lateral loading. The other test is used to research the effect of the depth of rock embedment for piles embedded in a foundation to simulate actual engineering applications in an experimental study. According to these test results, a detailed analysis was carried out on the relationships, such as the stress-strain and load-displacement relationships for the specimen. These tests show that the steel tube thickness and steel bars will significantly enhance the lateral bearing capacity and rigidity of the composite components. Additionally, the ultimate bending moment formula of a steel tubereinforced concrete pile is deduced. The comparison of the calculated results with the experimental results shows that this formula is applicable for this type of pile foundation.
\end{abstract}

\section{Introduction}

Concrete-filled steel tube (CFST) members are well recognized for their excellent performance owing to the combination of the merits of steel and concrete materials. Therefore, CFSTs are increasingly used in many structural applications, including columns supporting platforms of offshore structures, roofs of storage tanks, bridge piers, piles, and columns in seismic zones [1].

In 1957, since Kloppel and Goder et al. [2] reported their study of concrete-filled steel tubes, scholars from various countries have conducted extensive and in-depth experimental studies of these structures. In 1967, Furlong [3] reported the results of axial and compressive bearing tests of 52 CFSTs. In 1993, Grauers [4] carried out an experimental study on high-strength concrete-filled steel tubes; in the experiments, the core of the concrete strength was found to be up to $103 \mathrm{MPa}$. In 2001, Elchalakani et al. [5] presented an experimental investigation of the flexural behavior of circular CFT subjected to large deformation pure bending where $d / t=12$ to 110 and compared the behavior of empty and void-filled, cold-formed circular hollow sections under pure plastic bending. In 2002, Zhao and Grezebieta [6] conducted axial and pure bending tests on interlayer concrete-filled steel tubes. Aval et al. [7] considered the problem of the bond slip and the combination of steel tube and concrete, and they used the fiber model method to analyze the load-deformation curve of the bending member under a cyclic load. More recently, Montuori and Piluso [8] reported the ultimate behavior of concrete-filled tubular (CFT) members subjected to nonuniform bending moment. Furthermore, a fiber model able to predict the ultimate response of CFT members was also presented and compared with the experimental results, and the comparison between experimental and numerical results shows a good agreement pointing out the accuracy of the proposed fiber model.

In the past, there has been extensive research on the behavior of CFST members subjected to axial compression [9-12], axial tension [13-16], and more complex loading conditions [17-22]. Compared with the previously conducted research in the above fields, relatively little work has been reported on the lateral loading behavior of CFST members. 
TABle 1: Concrete mix design.

\begin{tabular}{lcccccc}
\hline $\begin{array}{l}\text { Strength } \\
\text { grade }\end{array}$ & $\begin{array}{l}\text { Water to cement } \\
\text { ratio (mass ratio) }\end{array}$ & $\begin{array}{c}\text { Water-reducing } \\
\text { agent }\left(\mathrm{kg} / \mathrm{m}^{3}\right)\end{array}$ & $\begin{array}{c}\text { Cement } \\
\left(\mathrm{kg} / \mathrm{m}^{3}\right)\end{array}$ & $\begin{array}{c}\text { Water } \\
\left(\mathrm{kg} / \mathrm{m}^{3}\right)\end{array}$ & $\begin{array}{c}\text { Gravel } \\
\left(\mathrm{kg} / \mathrm{m}^{3}\right)\end{array}$ & $\begin{array}{l}\text { Sand } \\
\left(\mathrm{kg} / \mathrm{m}^{3}\right)\end{array}$ \\
\hline C30 & 0.65 & 0 & 300 & 195 & 1220 & 685 \\
\hline
\end{tabular}

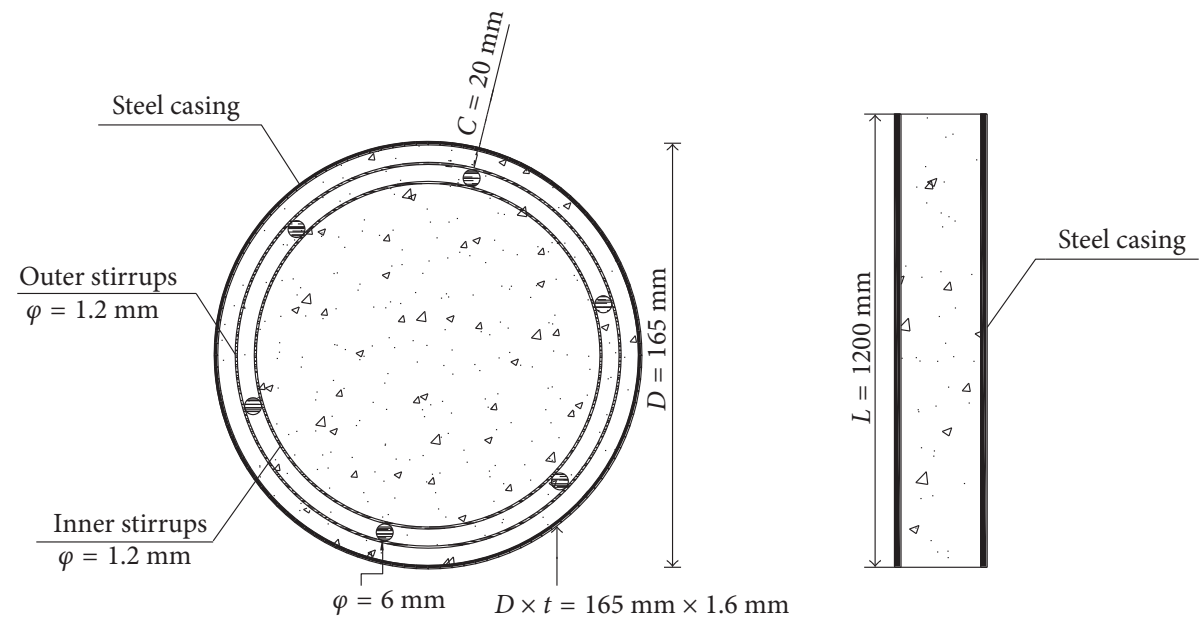

Figure 1: Specimen size.

The above literature review indicates that research on the lateral loading behavior of CFST members is still limited, especially for CFST members that have been widely used in engineering practices such as high-pile terminal structures and pile foundations. These applications utilize CFST members to not only bear the pile cap, beam, and other vertical loads but also bear a ship impact force and support other concentrations of the load. Under the action of horizontal loads, the pile foundation of a high-pile wharf has been used when the pile is broken. In this paper, in order to compare the influence of the thickness of a steel tube on the bearing capacity of composite members, a detailed experimental study on circular CFSTs has been undertaken under lateral loads. The bearing capacity of different types of concrete-filled steel tubular structures is discussed. Additionally, the influence of actual engineering applications on the depth of concrete-filled steel tubes was studied and analyzed.

\section{Experimental Study}

2.1. Material Properties. The steel tubes used for the construction of the CFST specimens were cold-rolled steel tubes. Young's modulus of the tube $(E)$ is $200 \mathrm{GPa}$, and the yield strength of the tube (fy) is $335 \mathrm{MPa}$. All the test specimens are scaled components. The specimens consist of the main bar and the stirrup, and the yield strength of the steel bars is $335 \mathrm{MPa}$. The core concrete material of the CFST is made of high-strength M30 cement mortar; this grout has the same elastic moduli as the actual pile. According to the code JGJ/T 98-2010 [23], the test mix design of all the specimens is shown in Table 1.

\subsection{Specimens without Foundation Tests}

2.2.1. Test Specimen Design. The specimens without foundation tests were used to study the behavior under a lateral load.
Column specimens with a length of $1200 \mathrm{~mm}$ were designed, as shown in Figure 1. The columns were reinforced with the main bar and the stirrup. Additionally, the main bar has a diameter of $6 \mathrm{~mm}$, and the stirrup has a diameter of $1.2 \mathrm{~mm}$. The stirrup spacing is $50 \mathrm{~cm}$ in the column. The distance between the outer stirrup and the steel casing is $20 \mathrm{~mm}$.

As summarized in Table 2, there were four specimens. The outer diameters of the tubes $(D)$ were $165 \mathrm{~mm}$. The section type of specimens NC1, NC2, and NC4 is the reinforced concrete section, and the section type of specimen NC3 is the concrete section. In addition, except for the specimen NC4, all other specimens have steel casing. And the thicknesses of the steel casing were $0 \mathrm{~mm}, 1.2 \mathrm{~mm}$, and $1.6 \mathrm{~mm}$, respectively.

2.2.2. Test Setup and Instrumentation. The test setup and instrumentation for the specimens are presented schematically in Figure 2. One servohydraulic actuator with a loading capacity of $500 \mathrm{kN}$ was used in the loading frame, which allows lateral forces to be applied to the dowel bar.

The experiment uses graded loading, and the specific loading method is as follows. The load is divided into 8 stages according to the estimated ultimate carrying capacity, but the load grading is not consistent: during the initial stage, each of the first few increments of loading was approximately $10 \%$ of the predicted failure load, but the loading is gradually reduced after the plastic stage of deformation is reached.

As shown in Figure 2, the deformation is measured by using dial indicators at the lower center and both ends of the specimen. The measuring range of the instrument is 0 to $50 \mathrm{~mm}$, and the maximum measurement accuracy is $0.01 \mathrm{~mm}$. The instrument can measure the absolute displacement and the relative displacement of the middle of the pile. 
TABLE 2: Details of the specimens.

\begin{tabular}{|c|c|c|c|c|c|c|c|}
\hline Specimen number & $D(\mathrm{~mm})$ & $t(\mathrm{~mm})$ & $L(\mathrm{~mm})$ & Section type & Steel casing & $f_{\mathrm{cu}}(\mathrm{MPa})$ & $f_{\mathrm{y}}(\mathrm{MPa})$ \\
\hline $\mathrm{NC} 1$ & 165 & 1.2 & 1200 & Concrete section & $\mathrm{Y}$ & 30.20 & 335 \\
\hline $\mathrm{NC} 2$ & 165 & 1.6 & 1200 & Composite section & $\mathrm{Y}$ & 30.20 & 335 \\
\hline NC3 & 165 & 1.2 & 1200 & Composite section & $\mathrm{Y}$ & 30.20 & 335 \\
\hline $\mathrm{NC4}$ & 165 & 0.0 & 1200 & Composite section & $\mathrm{N}$ & 30.20 & 335 \\
\hline
\end{tabular}

Note. $D$ : sectional diameter of the circular steel tube; $t$ : wall thickness of the steel tube; $L$ : length of the specimens; composite section: reinforced concrete cross section; concrete section: concrete cross section; $f_{\text {cu }}$ : concrete cube compressive strength; $f_{\mathrm{y}}$ : yield strength of steel.

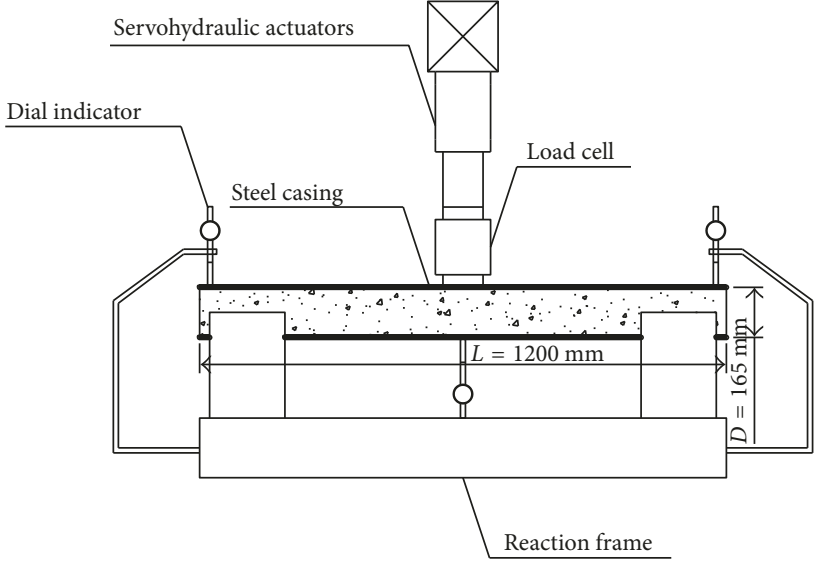

(a)

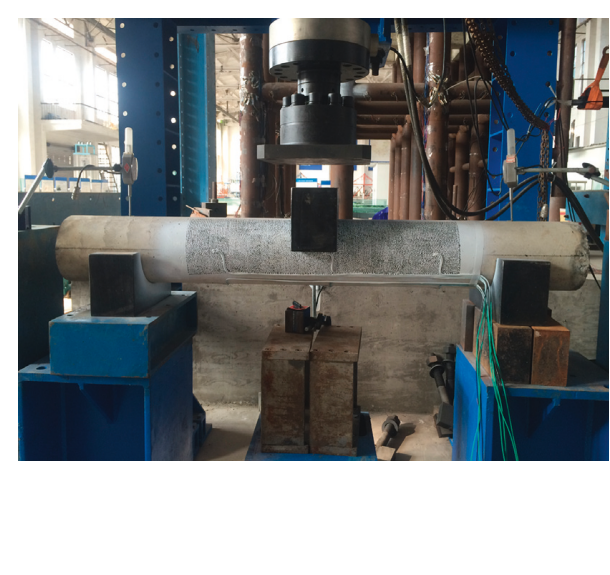

(b)

Figure 2: Test setup and instrumentation of specimens. (a) General view. (b) Photograph of loading device.

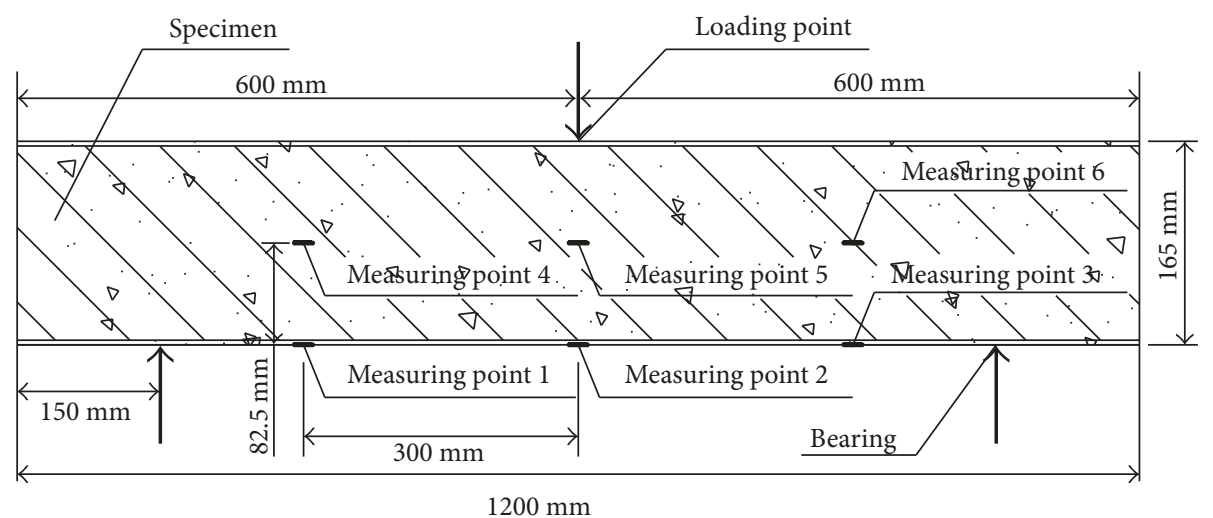

Figure 3: Point position map.

For this test, the strain gauges were attached to the pile side to measure the variation in the strain with the load. The distance between the first strain gauge and the column top and the distance between the bottom strain gauge and the pile bottom were both $30 \mathrm{~cm}$, and the distance between the adjacent strain gauge layers was $30 \mathrm{~cm}$. Each strain gauge measured the axial and lateral data. The experimental device schematic and strain gauge point position map are shown in Figure 3.

\subsection{Specimens with Foundation Tests}

2.3.1. Test Specimen Design. To further study the performance of CFSTs under lateral loading, additional tests were performed. These tests simulate the actual engineering conditions, and the specimen is embedded in a foundation.

A total of six columns were tested in this study, including three specimens with steel casing and three specimens without steel casing. The specimen size is shown in Figure 4. The columns consist of the main bar and the stirrup. In addition, the main bar has a diameter of $6 \mathrm{~mm}$, and the stirrup has a diameter of $1 \mathrm{~mm}$. The stirrup spacing is $3 \mathrm{~cm}$ in the column.

Table 3 provides details of the column specimens $\mathrm{BC} 1$ to BC6. All the specimens were placed vertically into the foundation. The length of all the specimens was $800 \mathrm{~mm}$, and the thicknesses of the steel casing were $1 \mathrm{~mm}$. The outer diameters of the tubes $(D)$ were $100 \mathrm{~mm}$, and the distance between the stirrup and the steel casing is $5 \mathrm{~mm}$. The various 


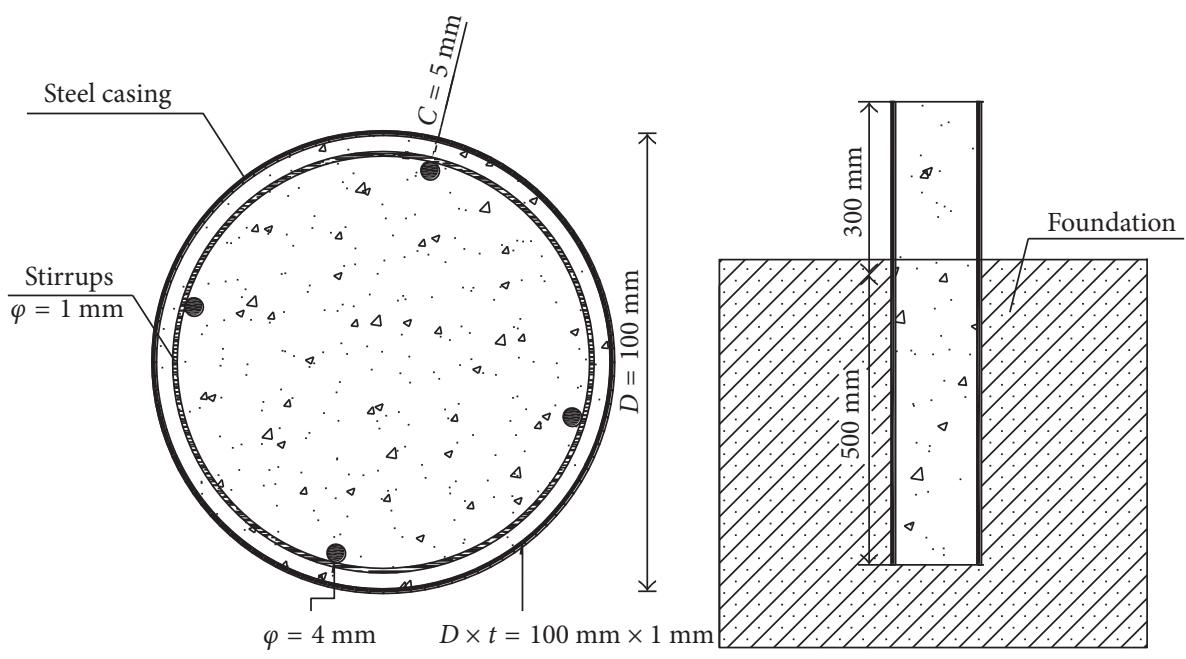

Figure 4: Specimen size.

Table 3: Details of the specimens.

\begin{tabular}{|c|c|c|c|c|c|c|c|}
\hline Specimen number & $D(\mathrm{~mm})$ & $t(\mathrm{~mm})$ & $L(\mathrm{~mm})$ & Rock-socketed depth (mm) & Steel casing & $f_{\mathrm{cu}}(\mathrm{MPa})$ & $f_{\mathrm{y}}(\mathrm{MPa})$ \\
\hline BC1 & 100 & 1 & 800 & 300 & $\mathrm{Y}$ & 31.32 & 235 \\
\hline BC2 & 100 & 1 & 800 & 300 & $\mathrm{~N}$ & 31.32 & 235 \\
\hline BC3 & 100 & 1 & 800 & 400 & $\mathrm{Y}$ & 31.32 & 235 \\
\hline $\mathrm{BC} 4$ & 100 & 1 & 800 & 400 & $\mathrm{~N}$ & 31.32 & 235 \\
\hline BC5 & 100 & 1 & 800 & 500 & $\mathrm{Y}$ & 31.32 & 235 \\
\hline BC6 & 100 & 1 & 800 & 500 & $\mathrm{~N}$ & 31.32 & 235 \\
\hline
\end{tabular}

Note. D: sectional diameter of the circular steel tube; $t$ : wall thickness of the steel tube; $L$ : length of the specimens; $f_{\text {cu }}$ : concrete cube compressive strength; $f_{\mathrm{y}}$ : yield strength of steel.

parameters considered in this investigation were the rocksocketed depth and the steel casing.

The rock-socketed portion of the specimen was placed in the simulated foundation. The model foundation size is $2.4 \mathrm{~m} \times 1.3 \mathrm{~m} \times 1 \mathrm{~m}$, and the concrete strength is low to simulate strong weathering mudstones. The concrete mix ratio is $12.5 \%$ cementitious material, $12.5 \%$ gravel, and $50 \%$ sand. In addition, the loading device is a separate servohydraulic actuator with a loading capacity of $100 \mathrm{kN}$, and it was placed on the top, and the top of the servohydraulic actuator was fixed on the reverse beam. A schematic diagram of the device setup is shown in Figure 5.

2.3.2. Test Setup and Instrumentation. In the test, the loading of the pile top is measured by the load sensor. The displacement of the pile top and the lateral displacement at the rock surface are measured by a displacement transducer. The strain gauge is used to measure the axial strain and the lateral strain of the concrete pile. The strain gauges are shown in Figure 6. During step-by-step loading, to keep each load the same, the load is calculated according to $10 \%$ of the estimated carrying capacity. The first stage load is 2 times the grading load; the unloading is reduced by a consistent $20 \%$ of the carrying capacity. The requirements are that the transmission load is uniform, continuous, and stable and that the time of loading is at least $1 \mathrm{~min}$.

\section{Results and Discussion}

This section presents the main experimental results of the tested CFST members, including the midspan loaddeflection, component strain-load, and lateral load $(P)$ versus lateral displacement curves. Analyses of the influence of the steel casing on the ultimate load-carrying capacity and the mechanisms driving these relationships are also performed. The influence of different test parameters on the behavior of the CFST members is also discussed.

\subsection{Specimens without Foundation Tests}

3.1.1. Midspan Load-Deflection Curve. The measured midspan deflection varies with the load of the regular curve, as shown in Figure 7.

From the load-deflection curve of Figure 7, the ultimate bearing capacities of the specimens with a steel guard are significantly improved: from specimens NC4 to NC2 and NC4 to NC3. According to the measured results, the ultimate bearing capacity of ordinary reinforced concrete piles is $30 \mathrm{kN}$; however, for the components with a steel tube thickness of $1.2 \mathrm{~mm}$, the ultimate bearing capacity is approximately $120 \mathrm{kN}$, and for the specimen with a steel tube thickness of $1.6 \mathrm{~mm}$, the ultimate load capacity is 


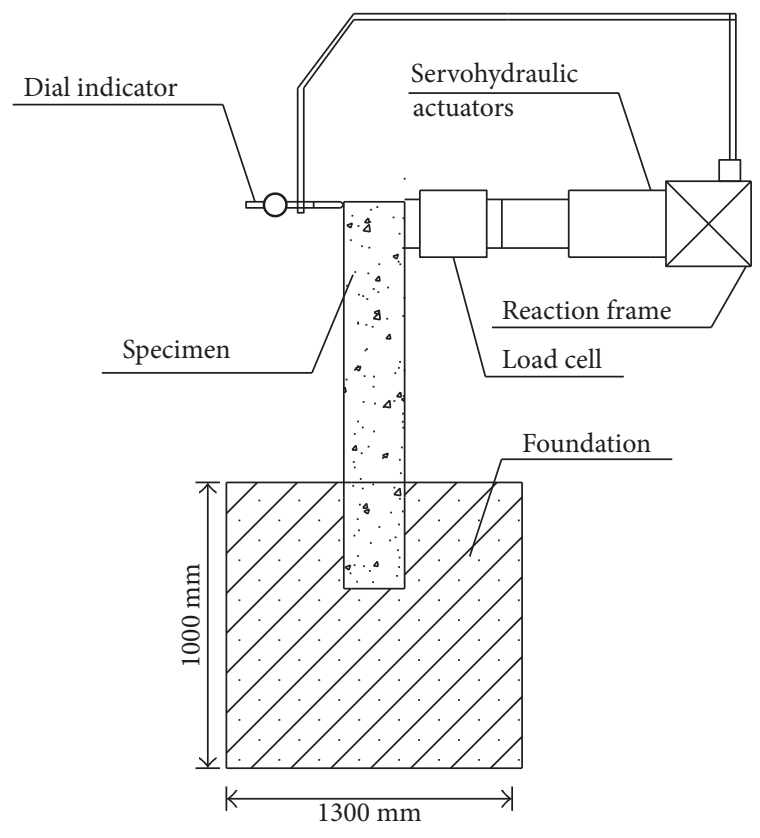

(a)

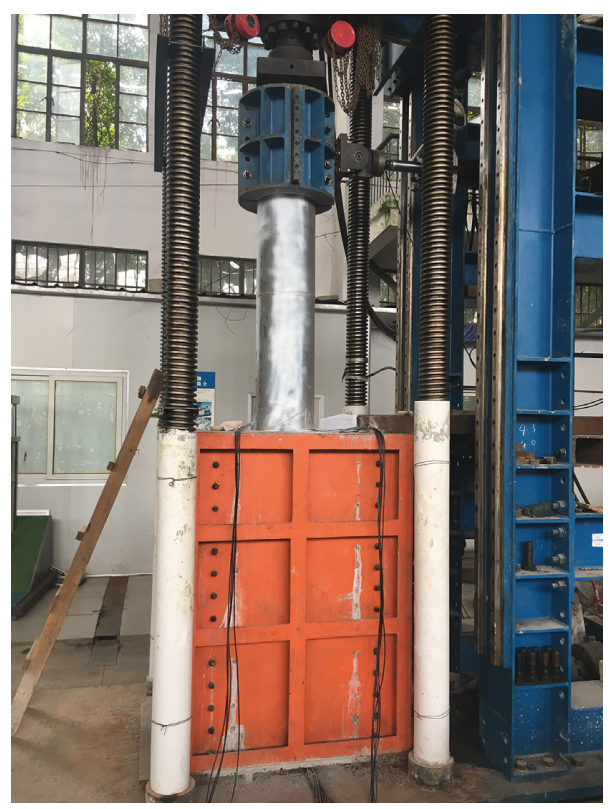

(b)

Figure 5: Test setup and instrumentation of specimens.

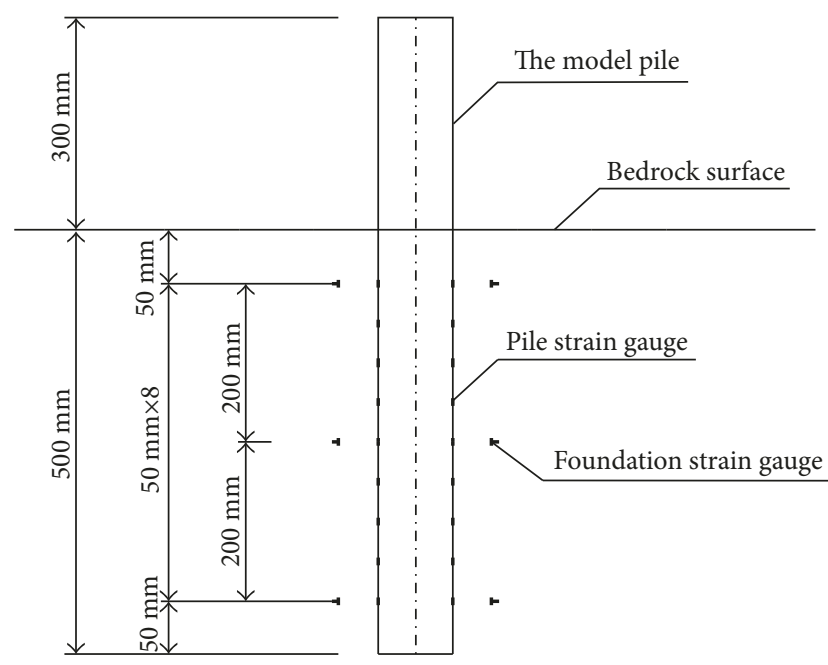

Figure 6: Test strain gauge layout diagram.

approximately $145 \mathrm{kN}$, which is 3-4 times bearing capacity of the reinforced concrete component. The greater the thickness of the steel tube, the higher the ultimate carrying capacity.

As shown in Figure 7, for the reinforced concrete members, because of their smaller spans, during the entire loading process, the midspan deflection increases linearly with the increase or decrease in the load, and there is no elastic-plastic phase. In addition, with the addition of steel-retaining elements, during the loading process, as the load increases, the midspan deflection presented three working stages; the elastic phase is exhibited before the load reaches $70 \mathrm{kN}$. With a linear increase in the load, the midspan deflection then enters the elastoplastic stage. Before the load increases to $110 \mathrm{kN}$, the

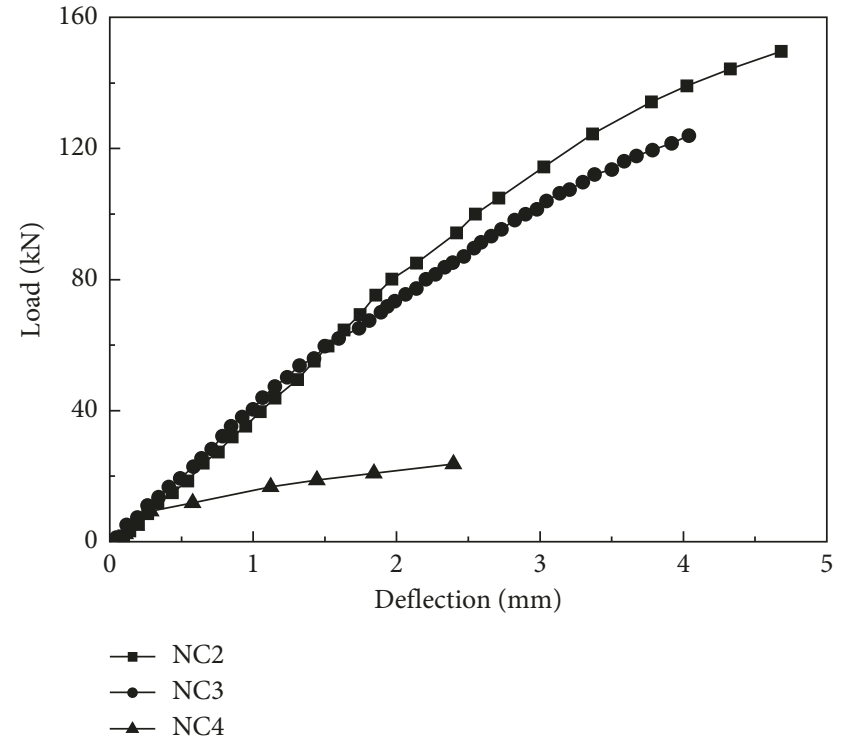

Figure 7: Specimen load-deflection curve.

components exhibit elastoplasticity; as the load continues to increase, the plastic phase is observed until the component is failure.

3.1.2. Strain-Load Curve. The variation in the strain of the reinforced concrete pile foundation model with the load is shown in Figure 8; here, only longitudinal observations are made for the pile foundation.

From Figure 8(a), we can see that the transverse strain of the reinforced concrete in the center of the pile is considerably greater than the strain at both ends. For a more intuitive 


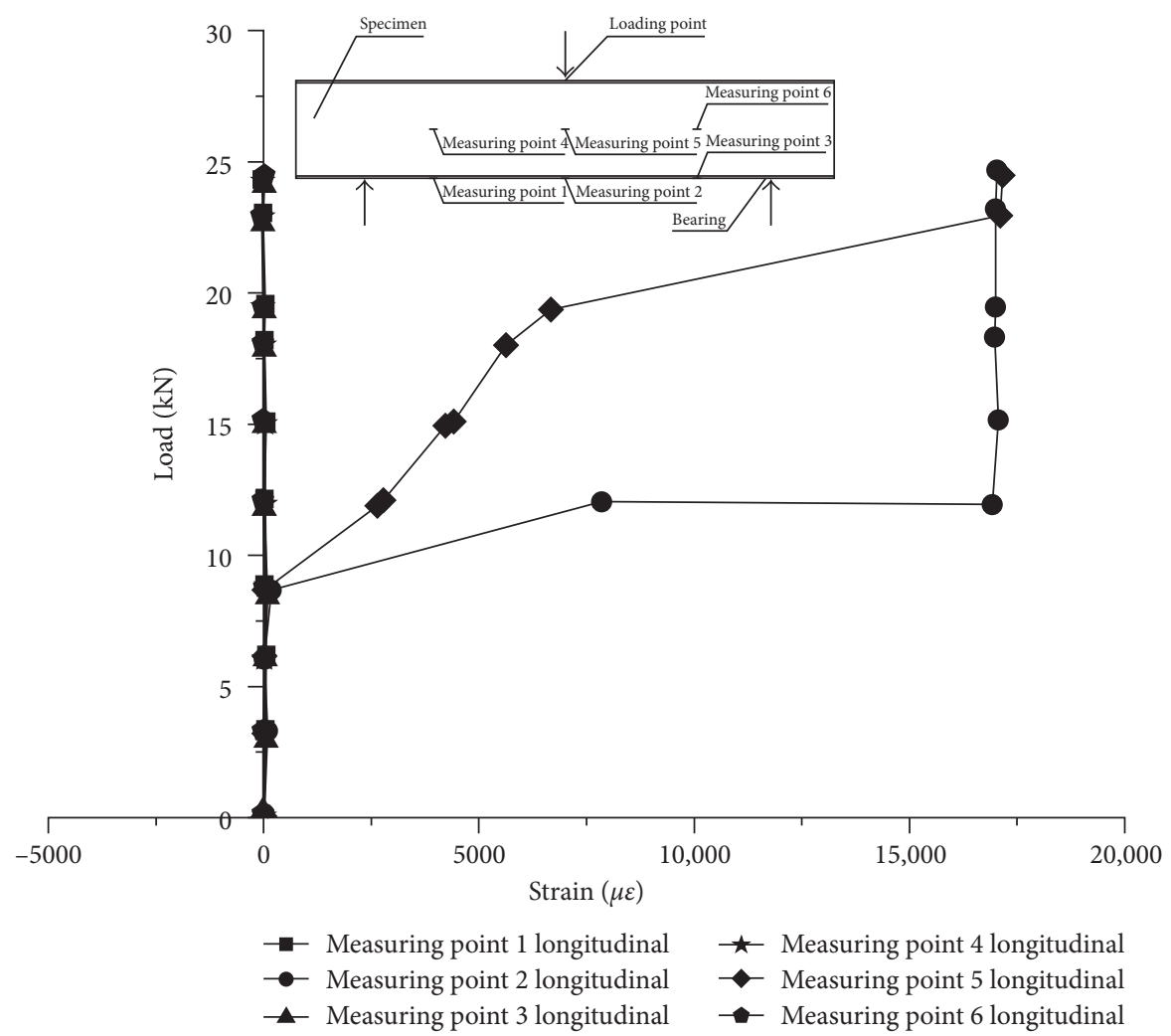

(a)

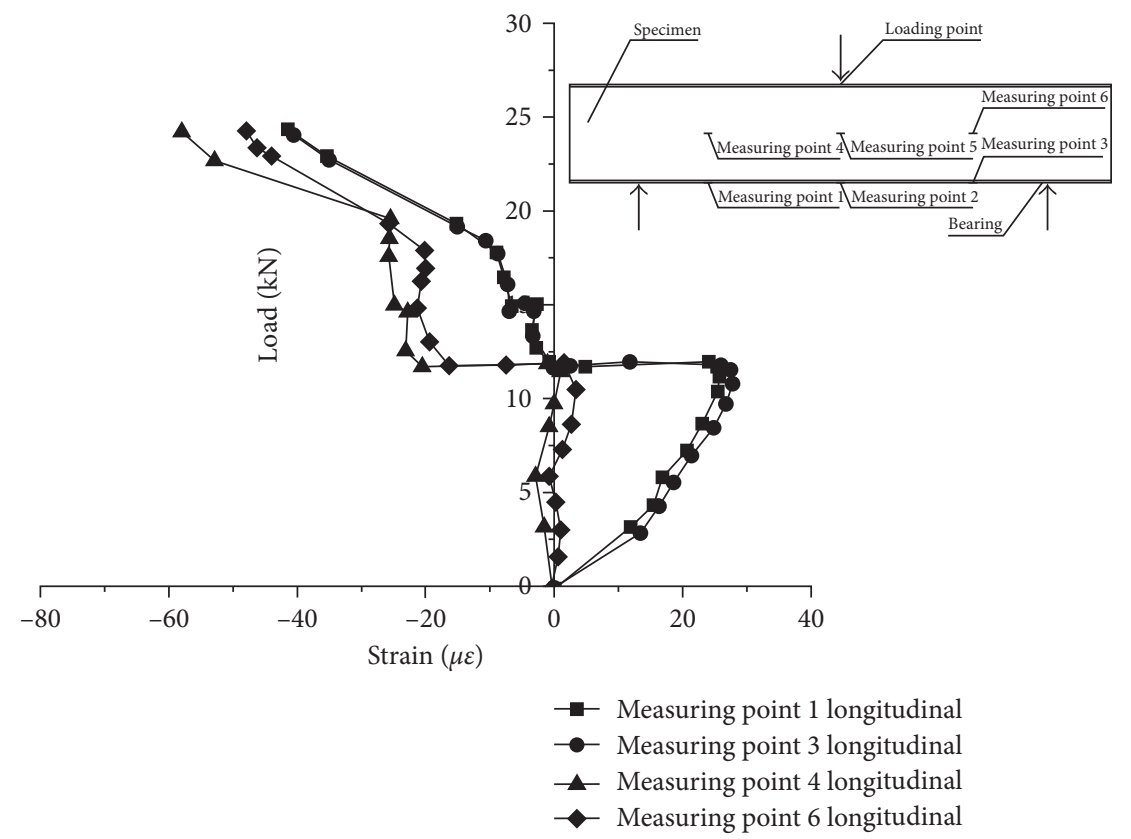

(b)

FIGURE 8: Strain-load curves for specimen NC4: (a) all the measuring points and (b) several of the measuring points.

expression of the end strain, the measured strain at point 1 , point 3 , point 4, and point 6 are shown in Figure 8(b). Figure 8(a) shows that when the load increases to approximately $10 \mathrm{kN}$, the axial strain increases rapidly, and the concrete in the tension zone is cracked and rapidly propagates toward the neutral surface. The reinforced concrete members exhibit brittle failure under a concentrated load, as shown in Figure 9. It can be seen from Figure 8(b) that, in the pile bottom at point 1 and point 3 , the ring strain has a large gap before the state is in a state of tension. After the cracks form, the strain value quickly becomes a pressure strain because the midspan cracks form, rapidly increasing the midspan deflection, and 


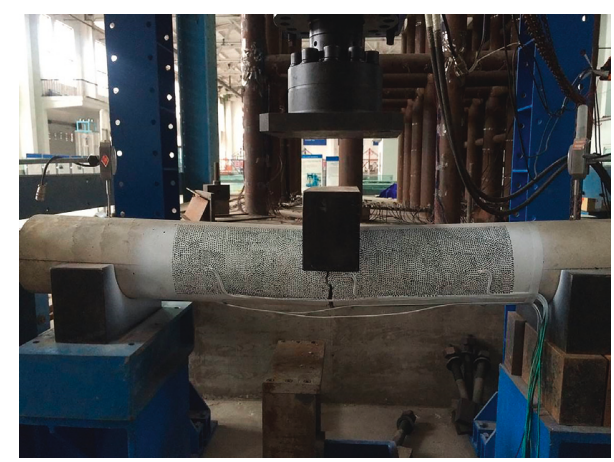

FIgURE 9: Brittle failure of reinforced concrete.

the concrete longitudinal fiber appears to be under a greater tensile strain. At this point, the measuring point 1 and the measuring point 3 of the concrete fiber are still in the elastic phase, so the tensile ring strain quickly decreases to 0 . In addition, as the load increases, a pressure strain develops. In addition, at the side end of measuring point 4 and measuring point 6 , before reaching the applied load of $10 \mathrm{kN}$, the strain value is approximately 0 ; that is, before reaching the damaging load, the tensile zone of the pile has not yet been extended to its neutral surface. After the load reaches $10 \mathrm{kN}$, the strains at measuring point 4 and measuring point 6 begin to develop into compressive strains. According to the analysis, the main reason for this change is the same as the abovementioned change at points 1 and 3 .

The measured strain of the steel tube-reinforced concrete piles in a foundation during the change in loading is shown in Figures 10 and 11. For the specimen NC3, the strain gauge at point 6 was damaged and failed.

It can be seen from Figures 10 and 11 that lateral bending of steel casing-reinforced concrete pile foundation shows a marked ductility compared to the deformation of reinforced concrete pile foundations. The midspan tension zone (longitudinal measuring point 2) does not show a sudden increase in strain in Figure 8 but is characterized by first elasticity and then elastoplasticity. Therefore, the use of steel tube protection has a very important role in the ductility of the pile foundation under enhanced lateral bending. At the same time, in addition to the cross-measuring point 2 , the other sides of the steel tube have longitudinal and circumferential strains that change linearly with the load, and the ratio of the longitudinal strain and circumferential strain is approximately Poisson's ratio of the steel casing. Therefore, during the entire loading process, in addition to measuring point 2 , the rest of the measuring point along the steel tubes are in the elastic phase. This phenomenon shows that using a steel tube greatly enhances the integrity of the pile. Unlike under axial compression, the effect of the steel tube on the core concrete is always present when a load is applied. Through the longitudinal and circumferential strain curves, we can see that, in the ring, the steel tube anchor strain is small; that is, the ring deformation is small. The analysis shows that this is the result of the interaction between the steel tube itself and the concrete. On one hand, the longitudinal stretching of the steel tube under tension causes the ring to shrink so that the steel tube in the ring produces pressure strain. On the other hand, the lateral deformation of the embedded concrete in the tension zone causes the steel tube to produce a tensile strain, offsetting the circumferential strain in the steel tube. In addition, within a certain thickness, when the load is small (less than $70 \%$ of its lateral bending limit load), the effect of the steel casing thickness on the bearing capacity of reinforced pile is not apparent, but for the ultimate deformation of the pile foundation, the steel casing thickness plays a certain role; increasing the thickness of the steel tube can effectively enhance the ductility of the pile foundation.

According to the above analysis, in the elastic phase, due to the limitations of the embedded concrete, the steel tube deformation occurs in the tensile zone under a triaxial force state. At this point, the concrete bears a small tensile stress, and its main role is to limit the ring deformation of the steel tube. In the elastoplastic stage, with the increase in the deformation of the steel tube, the tube stress exceeds its proportional limit and extends from the midsection to both ends. At this later stage, the maximum tensile fiber of the steel tube is yielding and developing internally. After the steel tube yields, the strain increases rapidly; due to the greater longitudinal deformation, the concrete in the tension zone cracks. With the increase in the load, the concrete cracks quickly propagate, damaging the component.

\subsubsection{Lateral Load $(P)$ versus Lateral Displacement $(\Delta)$} Curves. The lateral load $(P)$ versus lateral displacement $(\Delta)$ curves for common specimens are presented in Figure 12. The load-displacement curve of the NC3 specimen is shown in Figure 12(c).

It can be seen from the figures that the loaddisplacement curve exhibits a typical elastoplastic trend, and the elastic-plastic demarcation point occurs at a load of $100 \mathrm{kN}$. In the elastic phase, the deformation of the specimen is similar to the development with a linear loaddisplacement relationship. When the load is increased past the cutoff point, the load-displacement curve enters the nonlinear phase, and the stiffness of the specimen decreases gradually. The change in the midspan displacement is accelerated until the specimen is destroyed. When the lateral load exceeds $100 \mathrm{kN}$, the steel cylinder of the upper part of the specimen buckles and deforms, the bending displacement is accelerated, and the load-displacement curve undergoes a nonlinear stage. When the specimen bearing capacity decreases as the loading continues, the steel casing will undergo brittle fracture, as shown in Figure 13.

The NC1, NC2, NC3, and NC4 load-displacement curves are shown in Figure 12. It can be seen by comparing the results that with the increase in the thickness of the steel tube, the transverse bearing stiffness and ultimate lateral bearing capacity of the specimen will increase. The restraint effect of the reinforced concrete on the core concrete will also improve the rigidity and ultimate bearing capacity of the specimen. When the specimen has no steel tube restraint, the stiffness, ultimate bearing capacity, and ultimate deformation of the NC4 specimen are significantly smaller 


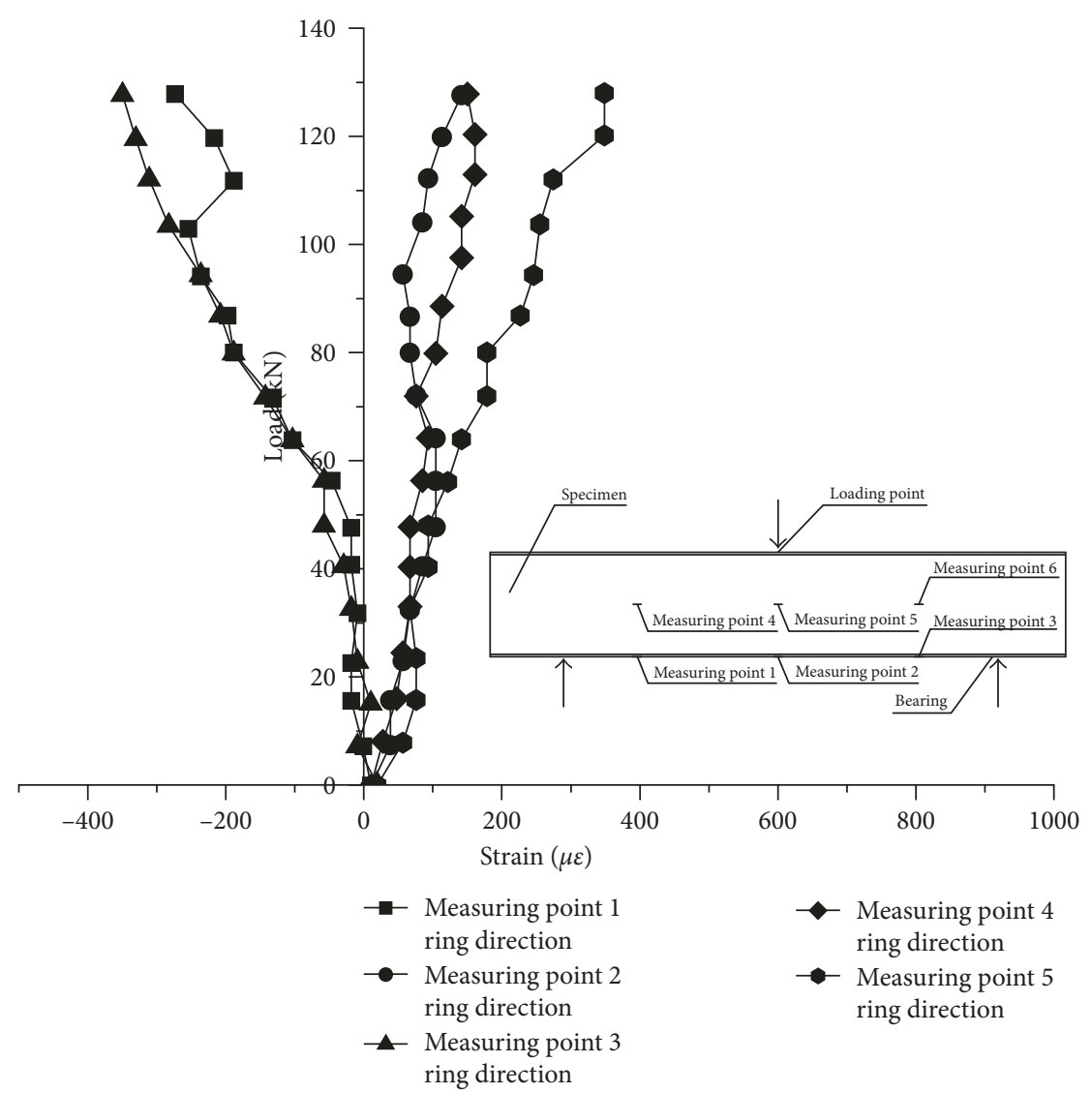

(a)

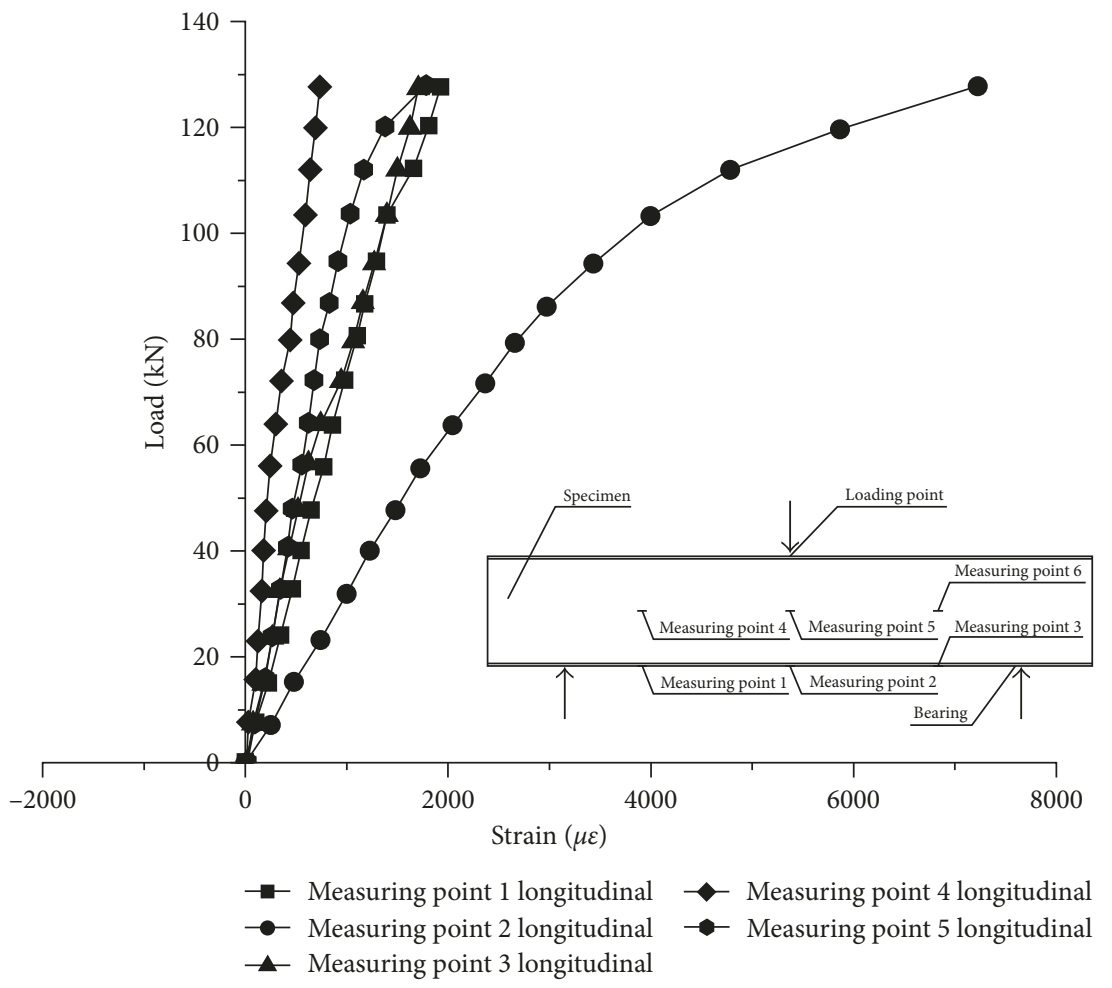

(b)

FiguRE 10: (a, b) Strain-load curves for each measuring point of specimen NC3. 


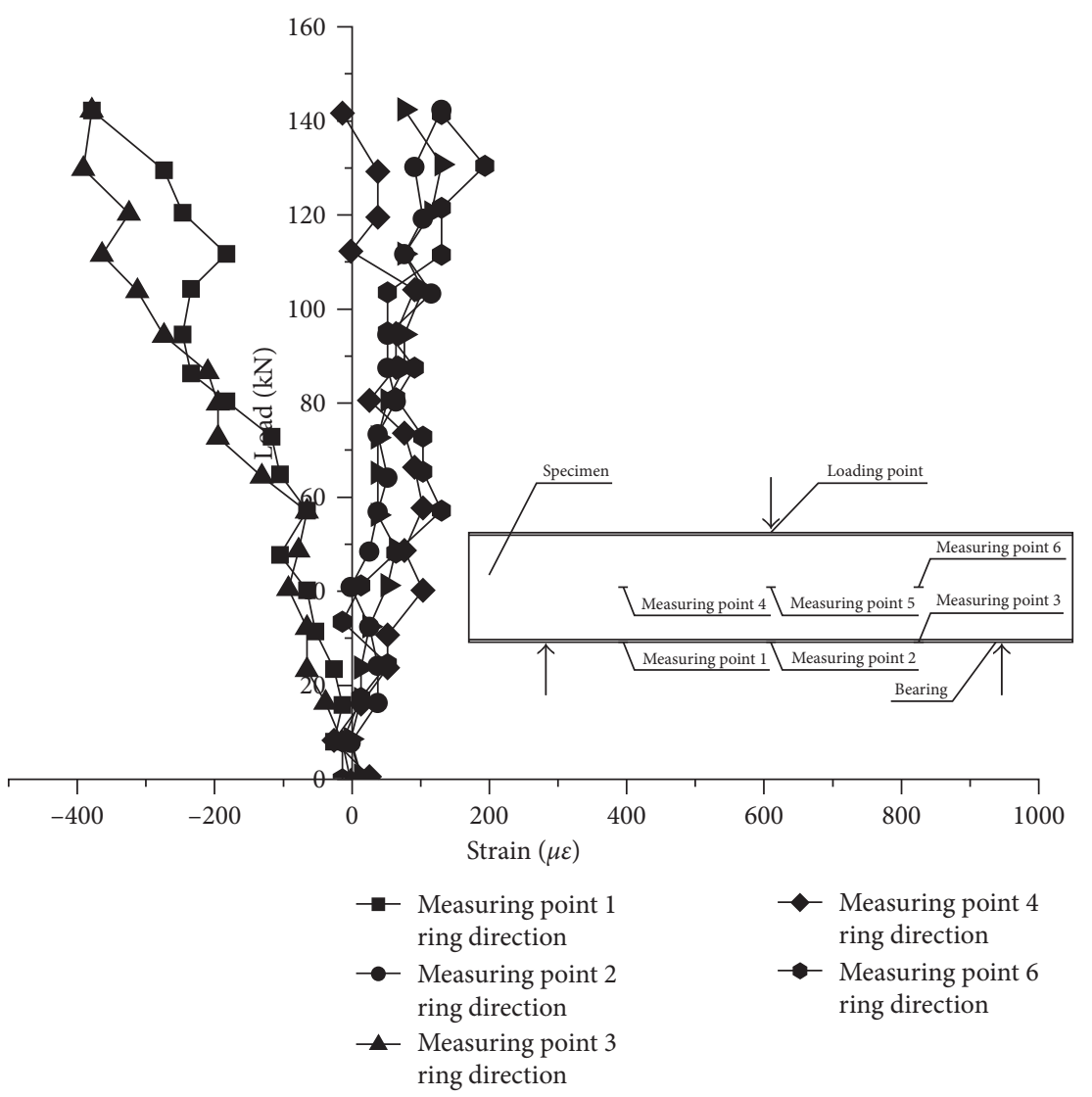

(a)

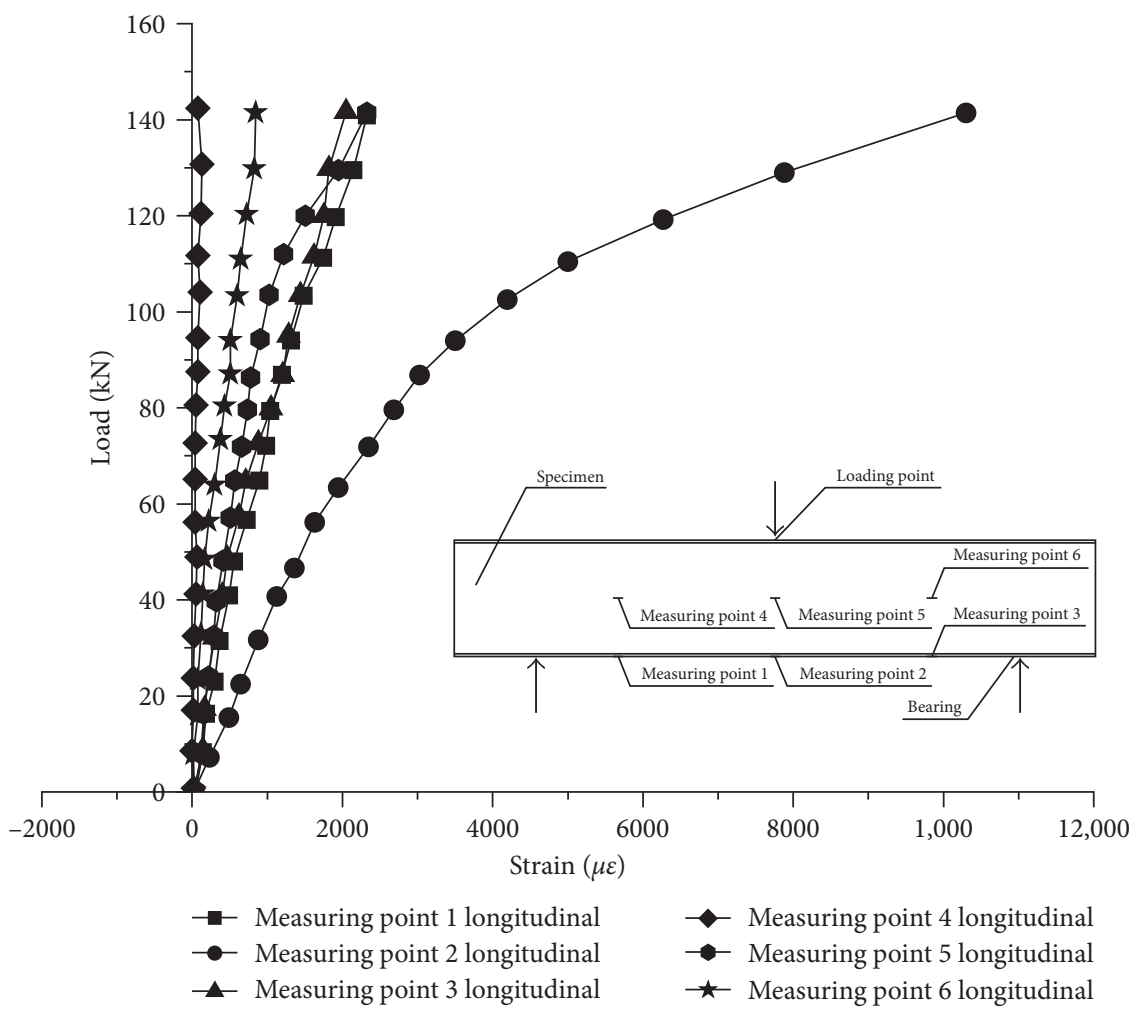

(b)

Figure 11: $(a, b)$ Strain-load curves for each measuring point of specimen NC2. 

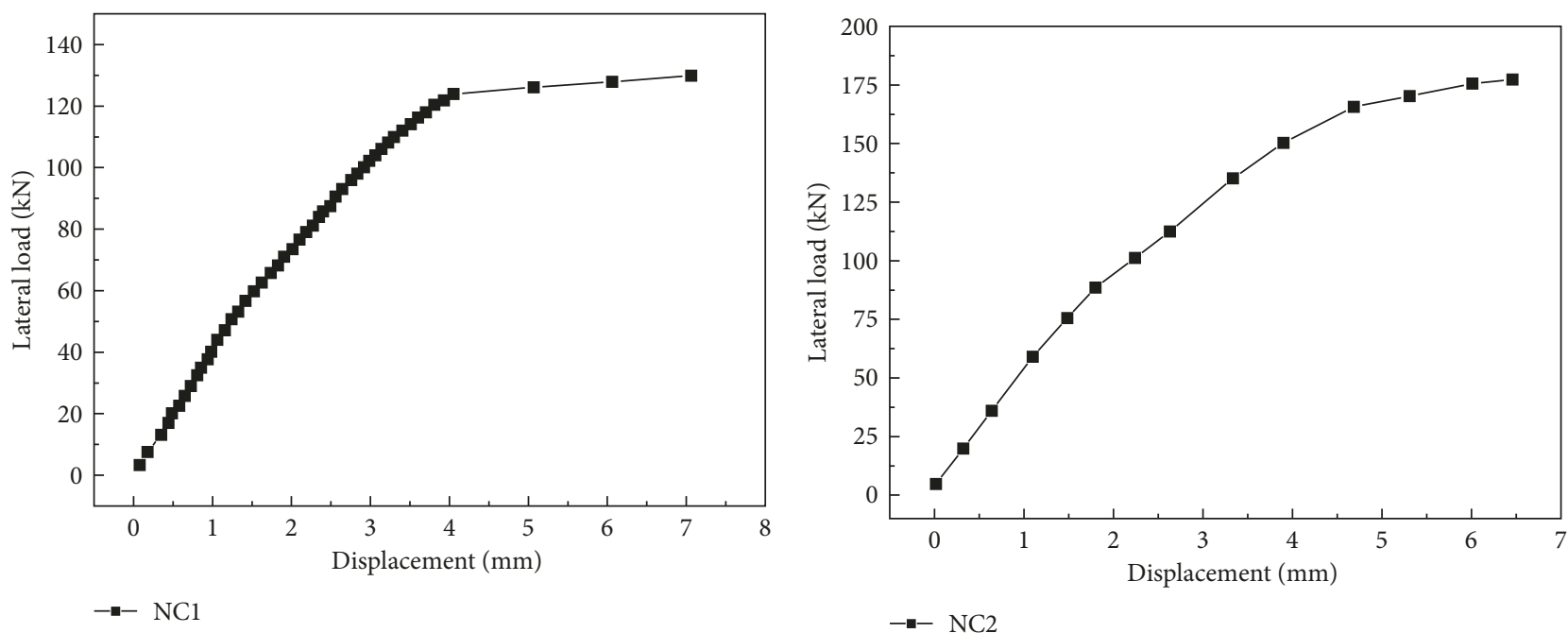

(a)

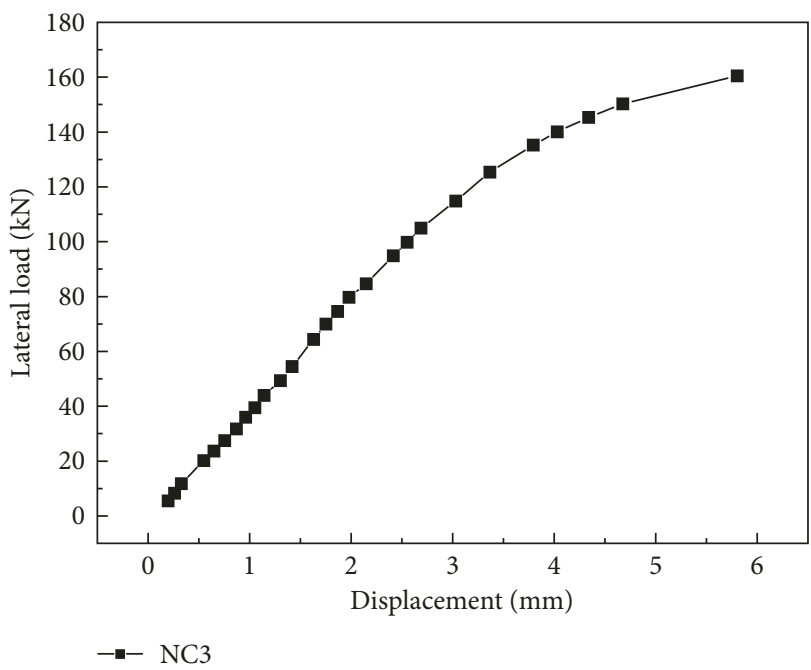

(c)

(b)

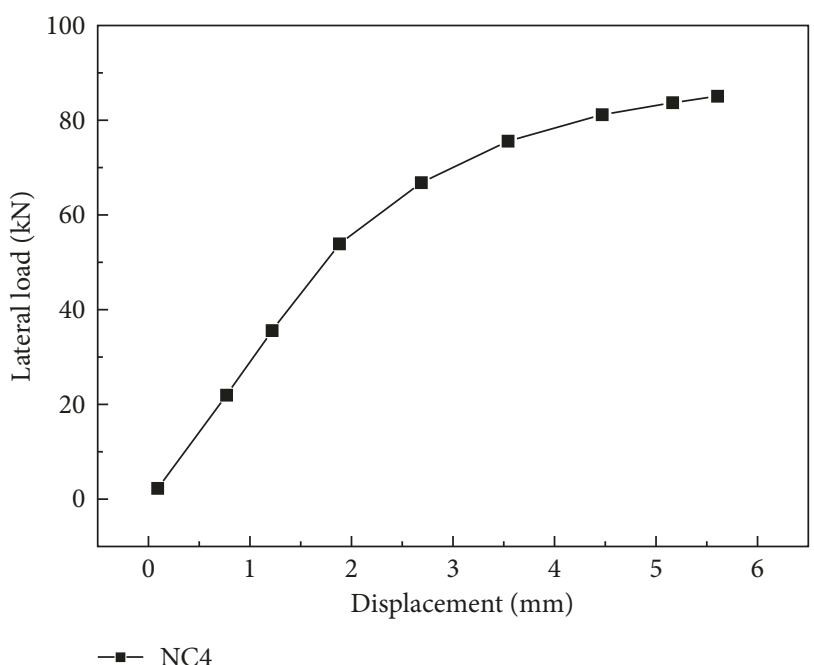

(d)

Figure 12: a-d) Lateral load $(P)$ versus lateral displacement $(\Delta)$ curves.

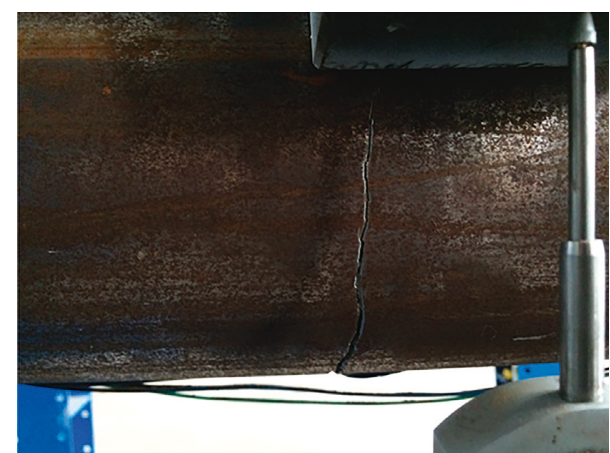

Figure 13: Brittle fracture of the steel casing of specimen NC3.

than the remaining three specimens. Therefore, when the steel-reinforced concrete composite components are used in practical engineering applications, the transverse bearing performance and deformation performance are obviously improved compared with those of the reinforced concrete and concrete-filled steel tubular members. The results of the tests of the four common specimens are summarized in Table 4.

\subsection{Specimens with Foundation Tests}

3.2.1. Failure Modes. After loading is complete, the excavation of the foundation is recorded for the failure of the model piles. The photographs show that the failure modes of the steel-embedded rock-socketed piles and common rocksocketed piles are considerably different under lateral loads. Figure 14 shows the failure mode of the two rock-socketed piles comparison chart; for an ordinary rock-socketed pile, the damage surface is tilted, and the tilt angle is approximately $45^{\circ}$. For rock-socketed piles with steel cages, the failure surface is horizontal and along the bottom of the tube. For these two kinds of piles, the location of the failure surface is not the same; the destruction surface of the common rocksocketed piles occurs across the surface of the foundation, 
TABLE 4: Test results of common specimens.

\begin{tabular}{|c|c|c|c|c|c|c|c|}
\hline Specimen number & $D(\mathrm{~mm})$ & $t(\mathrm{~mm})$ & $L(\mathrm{~mm})$ & Section type & Steel casing & $F_{\mathrm{u}}(\mathrm{kN})$ & $F_{\mathrm{ud}}(\mathrm{mm})$ \\
\hline $\mathrm{NC1}$ & 165 & 1.2 & 1200 & Concrete section & $\mathrm{Y}$ & 130.00 & 7.1 \\
\hline NC2 & 165 & 1.6 & 1200 & Composite section & $\mathrm{Y}$ & 177.00 & 6.4 \\
\hline NC3 & 165 & 1.2 & 1200 & Composite section & $\mathrm{Y}$ & 160.00 & 5.8 \\
\hline NC4 & 165 & 0.0 & 1200 & Composite section & $\mathrm{N}$ & 85.00 & 5.6 \\
\hline
\end{tabular}

Note. D: sectional diameter of the circular steel tube; $t$ : wall thickness of the steel tube; $L$ : length of the specimens; composite section: reinforced concrete cross section; concrete section: concrete cross section; $F_{\mathrm{u}}$ : ultimate bearing capacity of the concrete-filled steel tube; $F_{\mathrm{ud}}$ : ultimate deformation of the concrete-filled steel tube.

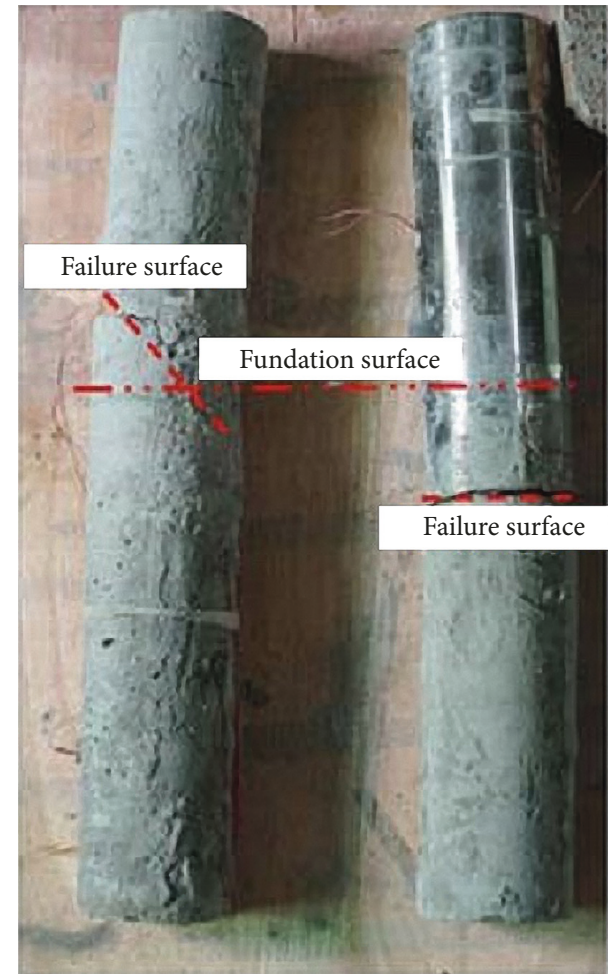

FIGURE 14: Comparison of failure modes of the two rock-socketed piles.

and the damage surface of the steel tube rock-socketed pile is buried under the surface of the foundation.

3.2.2. Load-Deflection Curve. Horizontal loads were applied to the six model piles; the lateral deformation of the pile top was measured by the horizontal displacement gauge at the top of the pile to better analyze the effect of steel casing on the bearing capacity of rock-socketed piles. The six groups of load-deflection curves, each representing a different rockembedment depth, are drawn in Figures 15(a)-15(c).

From Figures 15(a)-15(c), it can be seen that the influence of the steel casing on the horizontal bearing capacity of the rock-socketed piles is basically the same. It can be seen from Figure 15 that the load-deflection curves of the two rock-socketed piles are generally nonlinear but are linear under small loads. For the model pile BC1, when the horizontal displacement is less than $3 \mathrm{~mm}$, the horizontal displacement of the pile top increases linearly with the lateral load. When the horizontal displacement exceeds $3 \mathrm{~mm}$, the load of the pile has a small fluctuation; when the horizontal displacement of the pile is approximately $9 \mathrm{~mm}$, the horizontal load reaches maximum, which is the horizontal limit load capacity of the pile. For pile BC2, when the horizontal displacement is less than $6 \mathrm{~mm}$, the horizontal displacement of the pile top increases linearly with the lateral load. When the horizontal displacement exceeds $6 \mathrm{~mm}$, it changes nonlinearly with the load. When the horizontal displacement of the pile top is approximately $15 \mathrm{~mm}$, the ultimate load capacity is achieved. The horizontal ultimate loadcarrying capacity of rock-socketed piles is approximately $0.4 \mathrm{kN}$, while that of conventional rock-socketed piles is approximately $1.65 \mathrm{kN}$, indicating that the ultimate bearing capacity of rock-socketed piles is only $1 / 4$ of the common rock-socketed pile. In addition, the influence of the steel casing on the rock-socketed piles is basically the same: both kinds of steel-retaining cylinders will greatly reduce the horizontal bearing capacity of the pile body but slightly increase the deformation modulus.

Figure 16 shows the load-deflection curves of the rocksocketed piles with different rock-embedment depths.

It can be seen from Figure 16 that these three curves are linear at low loads and that the slope increases with the depth of embedment in the rock formation, indicating that the increase in the rock depth will increase the horizontal deformation modulus of the pile. The bearing capacity is approximately $0.45 \mathrm{kN}$ when the depth of the rock embedment is $300 \mathrm{~mm}$, the carrying capacity is approximately $0.70 \mathrm{kN}$ at $400 \mathrm{~mm}$, and the carrying capacity of $500 \mathrm{~mm}$ is reduced to $0.4 \mathrm{kN}$, showing that increasing the depth of the rock embedment does not always improve the carrying capacity.

3.2.3. Bearing Capacity. The bearing capacity of rocksocketed piles is affected by many factors. It can be seen from the horizontal load-deflection curves of the pile tops with different rock-embedded depths that the depth of rock embedment has a considerable influence on the bearing capacity of rock-socketed piles in common rock-socketed piles and those with steel cages. The slope of the loaddeflection curve shows the stiffness of the pile against lateral deformation; this relationship can be expressed by the following equation:

$$
W=\frac{F}{\lambda} .
$$

where $W$ is the stiffness, $F$ represents the horizontal load applied by the pile top, and $\lambda$ is the horizontal displacement 


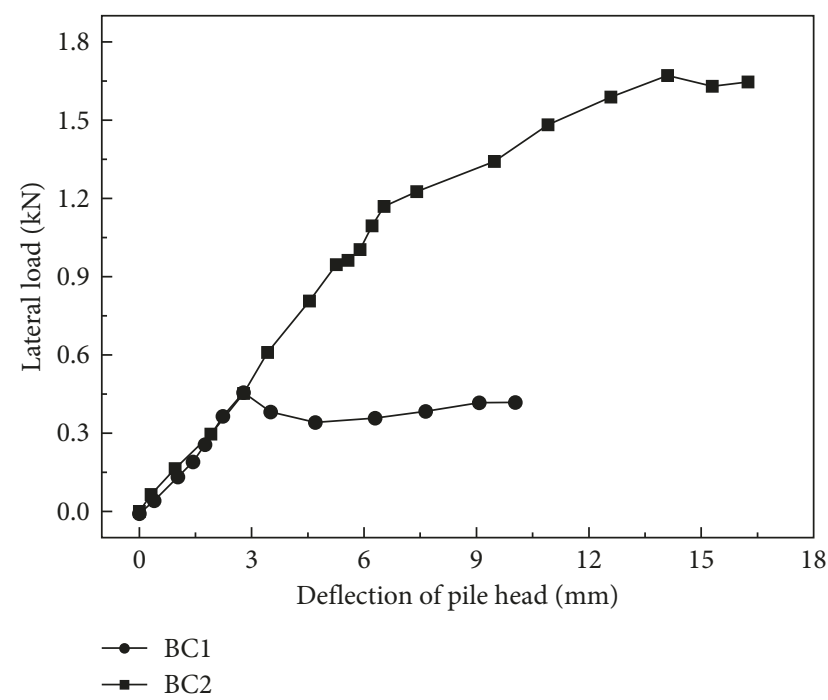

(a)

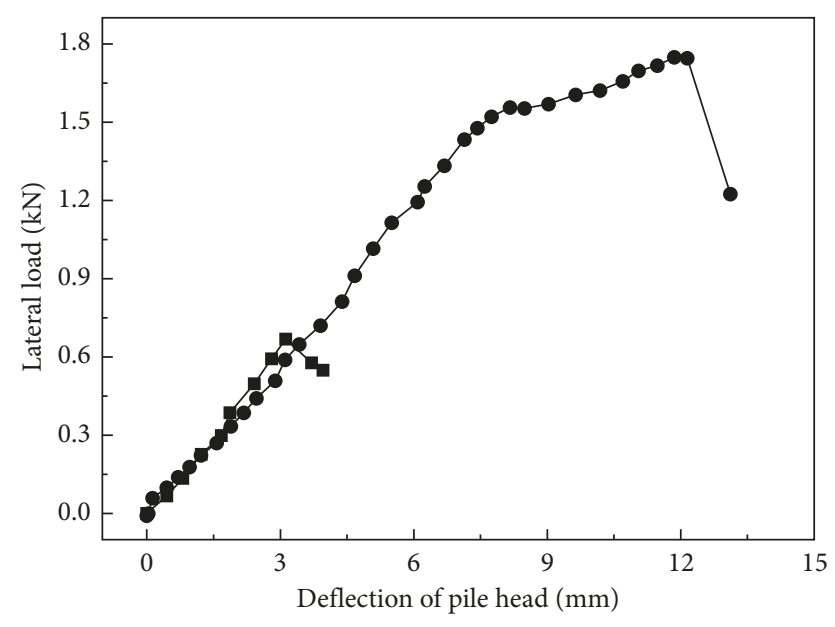

$\rightarrow \mathrm{BC} 3$

$\rightarrow \mathrm{BC} 4$

(b)

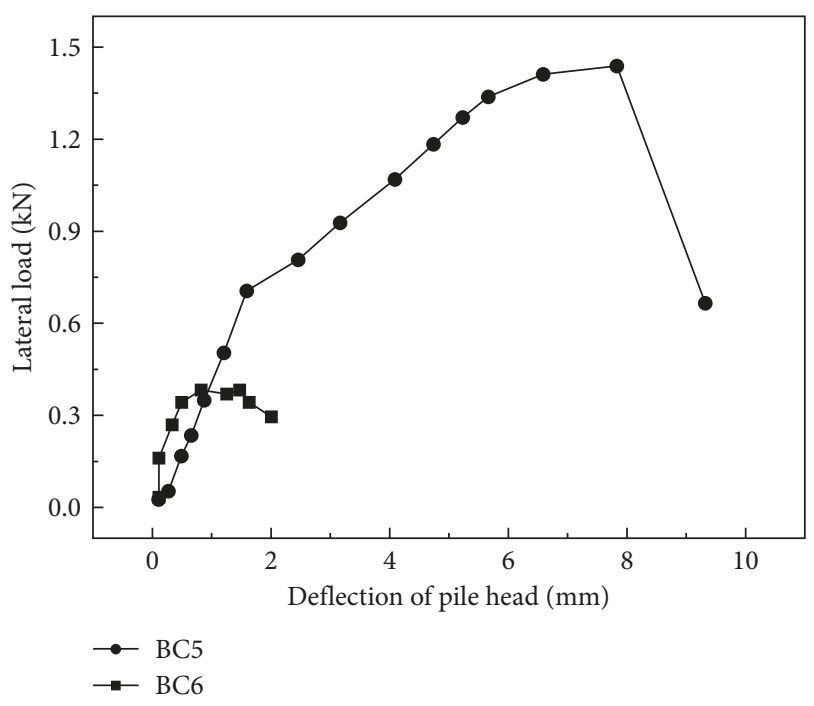

(c)

Figure 15: (a-c) Load-deflection curve.

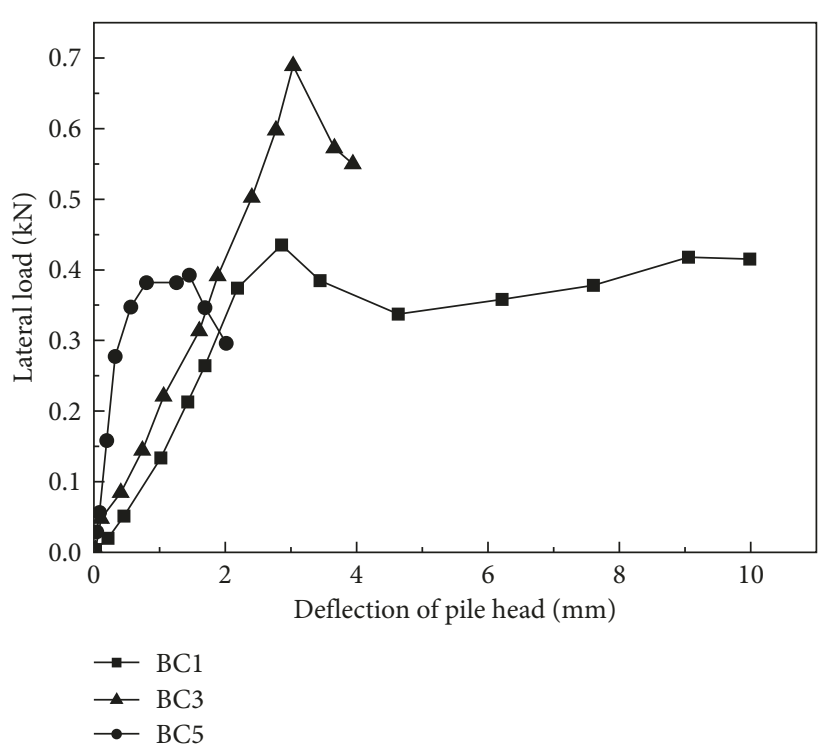

FIGURE 16: Load-deflection curve of rock-socketed piles with steelretaining tube.

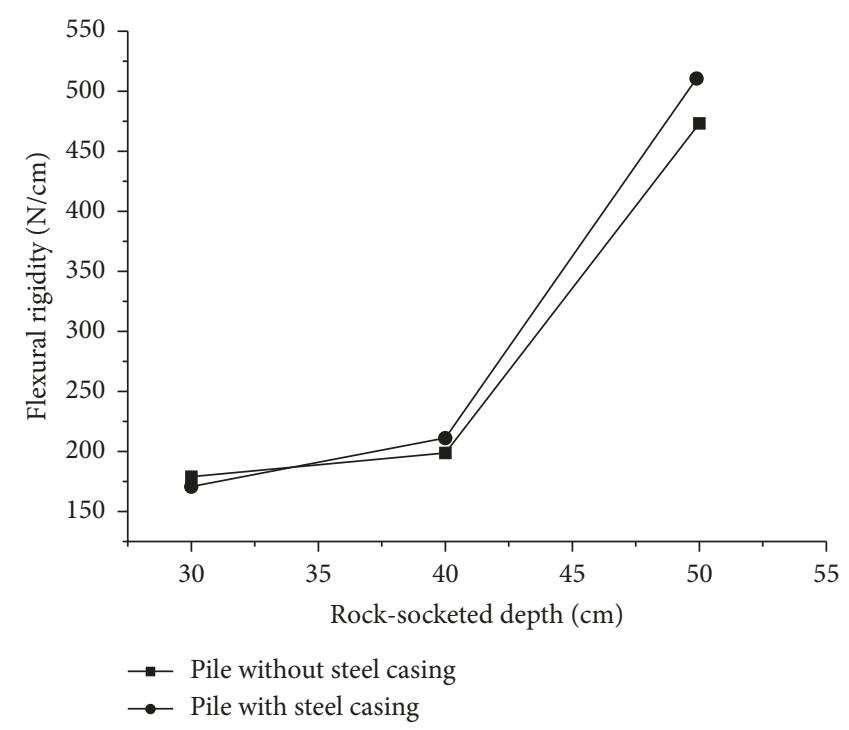

FIgURE 17: Comparison of the failure modes of the two kinds of rock-socketed piles.

of pile top. The relationship between the stiffness and rock depth is shown in Figure 17.

Figure 17 shows that the stiffness of the embedded rocksocketed piles and the steel-embedded rock-socketed piles increases with the depth of embedment of the pile in the foundation. As the rock-embedded depth increases from $40 \mathrm{~cm}$ to $50 \mathrm{~cm}$, the rigidity of the pile approximately doubles. When the rock-embedding depth is less than $40 \mathrm{~cm}$, which is less than 4 times the pile diameter, the rigidities of the two rock-socketed piles are very similar. When the depth of the rock-embedded rock is increased to $50 \mathrm{~cm}$, the rigidity of the rock-socketed pile is clearly greater than that of the ordinary rock-socketed pile, indicating that the steel tube enhances the stiffness of the pile. 
In addition to the lateral deformation stiffness, the horizontal ultimate bearing capacity of the pile can be determined by the load-deflection curve. Figure 18 shows the horizontal ultimate bearing capacity of the rock-socketed piles under different rock depths.

From Figure 18, we can see that the ultimate bearing capacity of the ordinary rock-socketed pile is much higher than that of the steel tube. When the depth of the rock-embedding increases from $30 \mathrm{~cm}$ to $40 \mathrm{~cm}$, the ultimate bearing capacity of the rock-socketed pile increases from $0.43 \mathrm{kN}$ to $0.74 \mathrm{kN}$; as the depth of embedment is increasing to $50 \mathrm{~cm}$, the ultimate bearing capacity did not continue to increase but instead reduced to $0.38 \mathrm{kN}$, which is less than that at the depth of $30 \mathrm{~cm}$ when the corresponding ultimate bearing capacity is also small. Comparing the rock-socketed piles with steel casing, the average ultimate bearing capacity of the ordinary rock-socketed piles is $1.5 \mathrm{kN}$, which is almost three times that of the rocksocketed piles. This shows that although the steel tube can increase the rigidity of the pile itself, the steel tube will also reduce the ultimate bearing capacity of the pile.

The main reason for the abovementioned phenomenon is that when the steel tube in the pile improves the rigidity, at the same time, the horizontal load applied to the top of the pile will be more concentrated on the upper part of the foundation, and the depth of the steel tube is only the pile diameter. Therefore, half of the bedrock in this very small area will bear a large part of the horizontal load, resulting in a very large bending moment in the pile cross section. From the failure mode of the pile, it can be seen that the failure surface of the rock-socketed pile is very large at the bottom of the steel tube, confirming the above analysis.

\section{Derivation of the Ultimate Moment Formula for Steel Casing-Reinforced Concrete Piles}

Han and Yang [24] and Cai [25] used a unified theory and limit equilibrium theory, respectively, to establish formulas for the ultimate bearing capacity of concrete-filled steel tubular members. In steel casing-reinforced concrete components, the transverse bending characteristics and concrete tube have some similarities. In this paper, the limit bending theory and the superposition principle are used to analyze the ultimate bending moment of steel tubereinforced concrete under transverse bending. The above derivation is described in $[24,25]$, which is directly referenced and adjusted in this section.

According to the principle of superposition, the ultimate bending moment is divided into three parts: the steel casing and reinforced double hoop under the action of concrete bending capacity, the steel tube bending capacity, and the bending capacity of steel, as shown in the following equation:

$$
M_{\mathrm{u}}=M_{\mathrm{u}}^{1}+M_{\mathrm{u}}^{2}+M_{\mathrm{u}}^{3},
$$

where $M_{\mathrm{u}}^{1}$ considers the steel casing and reinforced double hoop under the action of the concrete bending capacity, $M_{\mathrm{u}}^{2}$

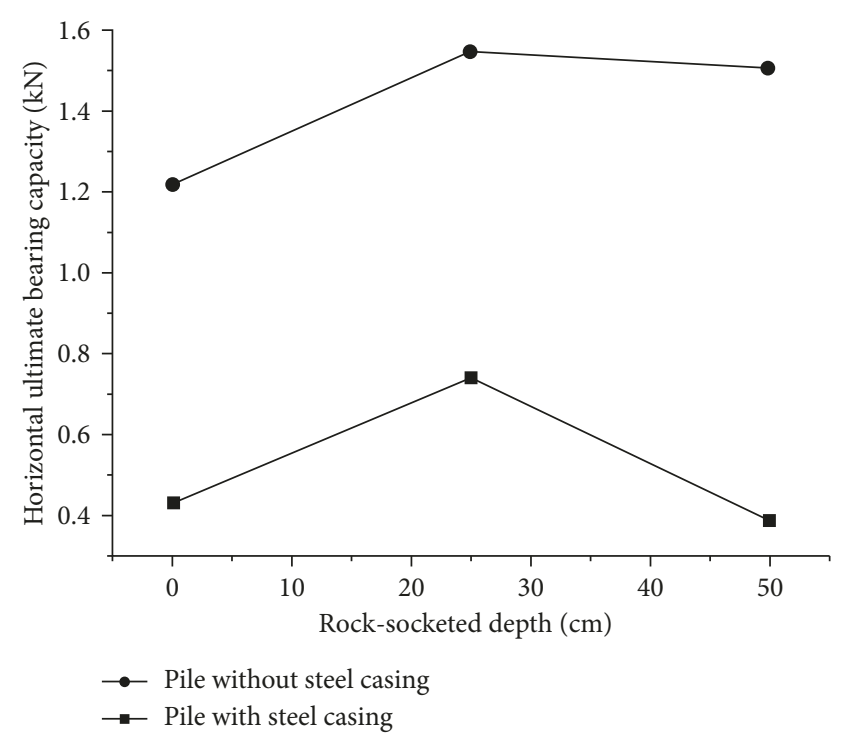

FIGURE 18: Horizontal ultimate bearing capacity of the rocksocketed piles under different depths of rock embedment.

is the flexural capacity of the steel tube, and $M_{\mathrm{u}}^{3}$ is the flexural capacity of the reinforcing bars.

Additionally, $M_{\mathrm{u}}^{1}, M_{\mathrm{u}}^{2}$, and $M_{\mathrm{u}}^{3}$ are calculated as follows:

$$
M_{\mathrm{u}}^{1}=W_{\mathrm{scm}} \gamma_{\mathrm{m}} f_{\mathrm{scy}},
$$

where $W_{\text {scm }}$ is the bending modulus of the concrete section according to the following formula:

$$
W_{\mathrm{scm}}=\frac{\pi(D-\delta)^{3}}{32}
$$

Additionally, $\gamma_{\mathrm{m}}$ is the calculation coefficient of the concrete bending capacity, according to the following formula:

$$
\begin{aligned}
\gamma_{\mathrm{m}} & =1.1+\theta_{1}+\theta_{2}, \\
\theta_{1} & =\frac{A_{\mathrm{S}} f_{\mathrm{y}}}{A_{\mathrm{C}} f_{\mathrm{C}}}, \\
\theta_{2} & =\frac{\rho f_{\mathrm{sy}}}{f_{\mathrm{C}}},
\end{aligned}
$$

where $f_{\mathrm{y}}$ is the yield strength of the tube, $A_{\mathrm{S}}$ is the steel cross-sectional area, $f_{\mathrm{C}}$ is the concrete cube compressive strength, $A_{\mathrm{C}}$ is the concrete cross-sectional area, and $\rho$ is the reinforcement ratio of concrete.

$f_{\text {scy }}$ is the strength index and considers $\theta_{1}$ when the concrete is under axial pressure according to the following formula:

$$
f_{\text {scy }}=\left(1.14+1.02 \theta_{1}\right) f_{\text {ck }} \text {, }
$$

where $f_{\mathrm{ck}}$ is the standard value of the concrete compressive strength.

$$
M_{\mathrm{u}}^{2}=W_{\mathrm{sy}} f_{\mathrm{y}},
$$

where $W_{\text {sy }}$ is the bending modulus of steel casing and is defined according to the following formula: 
TABLE 5: Parameters related to the limit bending moment.

\begin{tabular}{lcccccccc}
\hline $\begin{array}{l}\text { Specimen } \\
\text { number }\end{array}$ & $\begin{array}{c}W_{\mathrm{scm}} \\
\left(\mathrm{mm}^{3}\right)\end{array}$ & $\begin{array}{c}\gamma_{\mathrm{m}} \\
(\text { dimensionless })\end{array}$ & $\begin{array}{c}f_{\mathrm{scy}} \\
(\mathrm{MPa})\end{array}$ & $\begin{array}{c}W_{\text {sy }} \\
\left(\mathrm{mm}^{3}\right)\end{array}$ & $\begin{array}{c}W_{\mathrm{sb}} \\
\left(\mathrm{mm}^{3}\right)\end{array}$ & $\begin{array}{c}t \\
(\mathrm{~mm})\end{array}$ & $\begin{array}{c}\text { Calculation of the ultimate } \\
\text { bending moment }(\mathrm{kN} \cdot \mathrm{m})\end{array}$ & $\begin{array}{c}\text { Limit moment } \\
\mathrm{measurement}(\mathrm{kN} \cdot \mathrm{m})\end{array}$ \\
\hline NC2 & 431,460 & 1.17 & 40.93 & $25,784.2$ & 3333.4 & 0.276 & 27.32 & 28 \\
NC3 & 422,047 & 1.17 & 38.6 & $18,965.6$ & 3302 & 0.276 & 22.78 & 25.4 \\
\hline
\end{tabular}

Note. $W_{\mathrm{scm}}$ : bending modulus of the concrete section; $\gamma_{\mathrm{m}}$ : calculation coefficient of the concrete bending capacity; $f_{\text {scy }}$ strength index; $W_{\text {sy }}$ bending modulus of steel casing; $W_{\mathrm{sb}}$ : bending modulus of the steel; $t$ : thickness of the tube.

$$
W_{\text {sy }}=\frac{\pi\left\lceil D^{3}-(D-\delta)^{3}\right\rceil}{32} .
$$

Additionally, $f_{\mathrm{y}}$ is the yield strength of the steel casing.

$$
M_{\mathrm{u}}^{3}=W_{\mathrm{sb}} f_{y}^{\prime},
$$

where $W_{\mathrm{sb}}$ is the bending modulus of the steel according to the following method. The concrete inside the reinforcement is a continuous steel tube. When the radius of the tube is $\gamma_{\mathrm{s}}$, the thickness of the tube is $t$, and $\gamma_{\mathrm{s}}$ is the centerline radius of the reinforcement; the calculation of $t$ is determined according to the following formula:

$$
\begin{aligned}
t & =\frac{A_{\mathrm{s}}}{2 \pi \gamma_{\mathrm{s}}}, \\
W_{\mathrm{sb}} & =\frac{\pi\left\lceil\left(\gamma_{\mathrm{s}}+(t / 2)\right)^{3}-\left(\gamma_{\mathrm{s}}-(t / 2)\right)^{3}\right\rceil}{32} .
\end{aligned}
$$

According to (1), to calculate the ultimate bending moment for the steel tube-reinforced concrete pile foundation test in this chapter, the parameters of the calculation results are used, and these parameters and results are shown in Table 5:

It can be seen from Table 5 that the calculated results are in accordance with (2) and are in good agreement with the experimental results; therefore, this calculation can be used to determine the ultimate bending moment of a steel tubereinforced concrete pile foundation under transverse bending. However, due to the limited number of test groups and the rarity of related research, which failed to collect additional test results, the universal applicability of this calculation is not yet clear.

\section{Conclusions}

The behavior of CFSTs has been studied under lateral loads. Further research is also still needed on CFSTs that are used in the field. From the range of the test parameters studied in this paper, the following conclusions can be drawn based on the above results:

(1) The load-displacement curve of concrete-filled steel tubular reinforcement members under transverse loads shows a typical elastic-plastic trend. In addition, the steel casing will reduce the ultimate load capacity but will slightly increase the deformation modulus.

(2) The steel tube thickness and steel bars will significantly enhance the lateral bearing capacity and rigidity of the composite components; from the deformation point of view, the steel tube thickness and steel bars can effectively restrain the overall deformation of the composite components. For steel tube protection with different thicknesses and different reinforcement designs, the restraining effect is significantly different.

(3) Increasing the depth of embedment of the rocksocketed pile does not always improve the carrying capacity. The ordinary rock-socketed piles were damaged, and the angle of inclination is approximately $45^{\circ}$. The steel tube destruction surface is at the level of the rock foundation and along the bottom of the tube. In addition, the location of the failure surface in each type of pile is not the same.

(4) The formula for calculating the ultimate bending moment of a steel-retaining cylinder-reinforced concrete pile foundation under transverse bending is established by using the theory of ultimate strength and the superposition principle. The comparison of the calculated results with the experimental results shows that this formula is applicable for this type of pile foundation.

\section{Conflicts of Interest}

The authors declare that there are no conflicts of interest regarding the publication of this manuscript.

\section{Acknowledgments}

This study was financially supported by Chinese National Natural Science Foundation (nos. 51579021 and 51709026) and Chinese Ministry of Transportation West Project (nos. 2014328224040 and 2014328J26200).

\section{References}

[1] L. H. Han, W. Li, and R. Bjorhovde, "Developments and advanced applications of concrete-filled steel tubular (CFST) structures: members," Journal of Constructional Steel Research, vol. 100, no. 5, pp. 211-228, 2014.

[2] V. K. Kloppel and W. Goder, "An investigation of the load carrying capacity of concrete-filled steel tubes and development of design formula," Der Stahlbau, vol. 26, no. 1, pp. 1-10, 1957.

[3] R. W. Furlong, "Strength of steel-encased concrete beamcolumns," Journal of Structural Division, vol. 93, no. 5, pp. 113-124, 1967.

[4] M. Grauers, Composite Columns of Hollow Steel Sections Filled with High Strength Concrete, Division of Concrete Structures, Chalmers University of Technology, Goteborg, Sweden, 1993. 
[5] M. Elchalakani, X. L. Zhao, and R. H. Grzebieta, "Concretefilled circular steel tubes subjected to pure bending," Journal of Constructional Steel Research, vol. 57, no. 11, pp. 1141-1168, 2001.

[6] X. L. Zhao and R. H. Grezebieta, "Strength and ductility of concrete filled double skin tubes," Thin-Walled Structures, vol. 40, no. 2, pp. 199-213, 2002.

[7] S. B. B. Aval, M. A. Saadeghvaziri, and A. A. Golafshani, "Comprehensive composite inelastic fiber element for cyclic analysis of concrete-filled steel tube columns," Journal of Engineering Mechanics, vol. 128, no. 4, pp. 428-437, 2002.

[8] R. Montuori and V. Piluso, "Analysis and modelling of CFT members: moment curvature analysis," Thin-Walled Structures, vol. 86, pp. 157-166, 2015.

[9] B. Young and E. Ellobody, "Experimental investigation of concrete-filled cold-formed high strength stainless steel tube columns," Journal of Constructional Steel Research, vol. 62, no. 5, pp. 484-492, 2006.

[10] J. Y. R. Liew and D. X. Xiong, "Effect of preload on the axial capacity of concrete-filled composite columns," Journal of Constructional Steel Research, vol. 65, no. 3, pp. 709-722, 2009.

[11] X. L. Zhao, L. W. Tong, and X. Y. Wang, "CFDST stub columns subjected to large deformation axial loading," Engineering Structures, vol. 32, no. 3, pp. 692-703, 2010.

[12] N. Jamaluddin, D. Lam, X. H. Dai, and J. Q. Ye, “An experimental study on elliptical concrete filled columns under axial compression," Journal of Constructional Steel Research, vol. 87, pp. 6-16, 2013.

[13] L. H. Han, S. H. He, and F. Y. Liao, "Performance and calculations of concrete filled steel tubes (CFST) under axial tension," Journal of Constructional Steel Research, vol. 67, no. 11, pp. 1699-1709, 2011.

[14] W. Li, L. H. Han, and T. M. Chan, "Numerical investigation on the performance of concrete-filled double-skin steel tubular members under tension," Thin-Walled Structures, vol. 79, pp. 108-118, 2014.

[15] A. Y. Jiang, J. Chen, and W. L. Jin, "Experimental investigation and design of thin-walled concrete-filled steel tubes subject to bending," Thin-Walled Structures, vol. 63, no. 63 , pp. $44-50,2013$.

[16] R. Wang, L. H. Han, J. G. Nie, and X. L. Zhao, "Flexural performance of rectangular CFST members," Thin-Walled Structures, vol. 79, no. 2, pp. 154-165, 2014.

[17] S. H. Lee, B. Uy, S. H. Kim, Y. H. Choi, and S. M. Choi, "Behavior of high-strength circular concrete-filled steel tubular (CFST) column under eccentric loading," Journal of Constructional Steel Research, vol. 67, no. 1, pp. 1-13, 2011.

[18] V. I. Patel, Q. Q. Liang, and M. N. S. Hadi, "High strength thin-walled rectangular concrete-filled steel tubular slender beam-columns, part II: behavior," Journal of Constructional Steel Research, vol. 70, no. 2, pp. 368-376, 2012.

[19] T. Perea, R. Leon, J. Hajjar, and M. Denavit, "Full-scale tests of slender concrete-filled tubes: interaction behavior," Journal of Structural Engineering, vol. 140, no. 9, p. 04014054, 2014.

[20] W. Li, L. H. Han, and T. M. Chan, "Performance of concretefilled steel tubes subjected to eccentric tension," Journal of Structural Engineering, vol. 141, no. 12, p. 04015049, 2015.

[21] F. McCann, L. Gardner, and W. Qiu, "Experimental study of slender concrete-filled elliptical hollow section beamcolumns," Journal of Constructional Steel Research, vol. 113, no. 1, pp. 185-194, 2015.

[22] Z. B. Wang, Q. Yu, and Z. Tao, "Behaviour of CFRP externallyreinforced circular CFST members under combined tension and bending," Journal of Constructional Steel Research, vol. 106, no. 1, pp. 122-137, 2015.

[23] JGJ/T 98-2010, Specification for Mix Proportion Design of Masonry Mortar, China Architecture and Building Press, Beijing, China, 2010, in Chinese.

[24] L. H. Han and Y. F. Yang, Modern Steel Tube Confined Concrete Structures Technology, China Architecture and Building Press, Beijing, China, 2007, in Chinese.

[25] S. H. Cai, Modern Steel Tube Confined Concrete Structures (Revised Edition), China Communication Press, Beijing, China, 2007, in Chinese. 


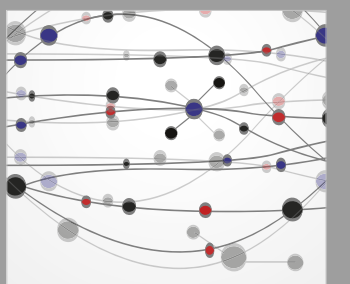

The Scientific World Journal
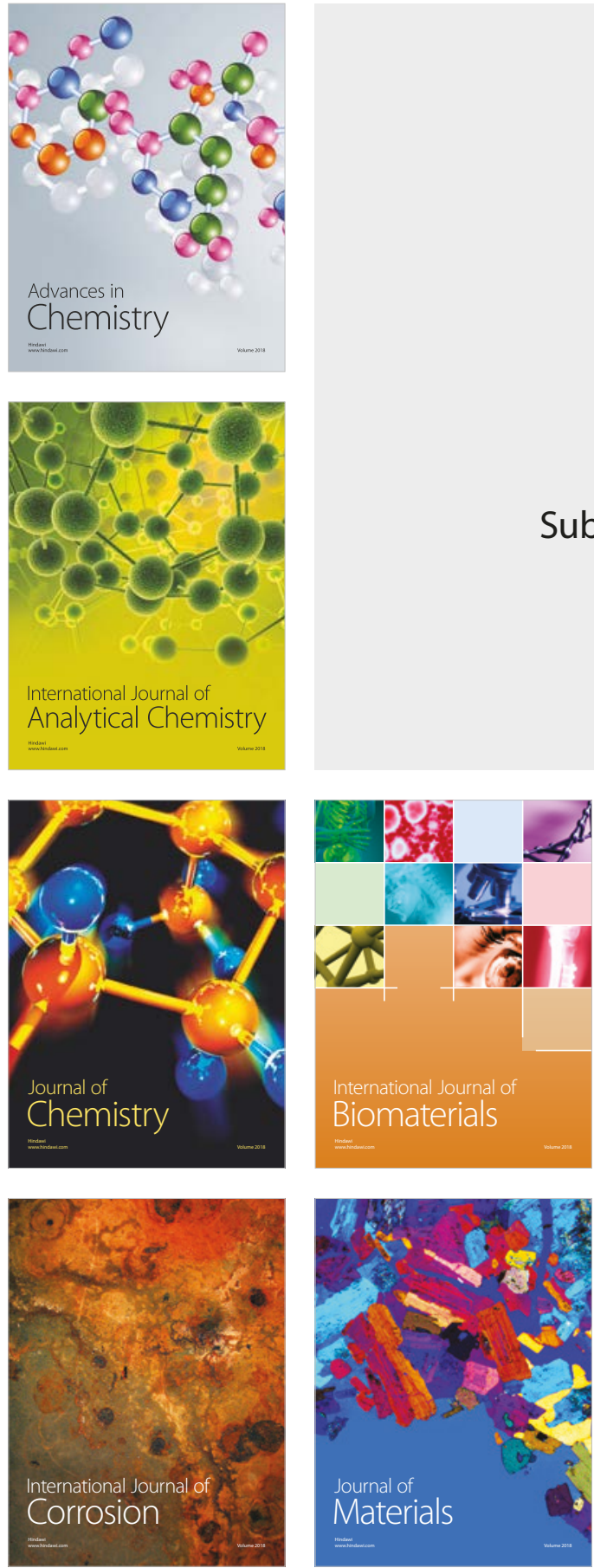

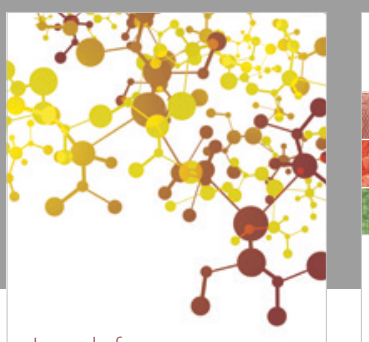

Journal of

Applied Chemistry
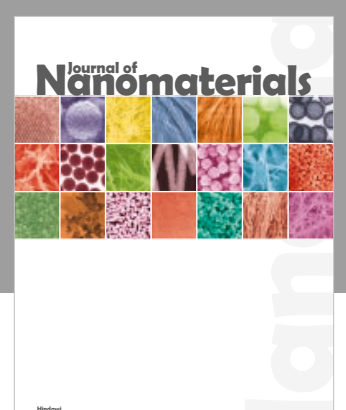

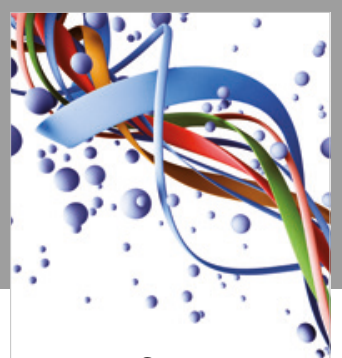

Scientifica

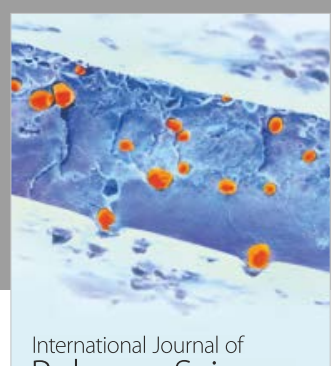

Polymer Science

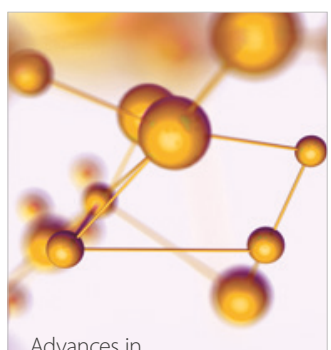

Physical Chemistry
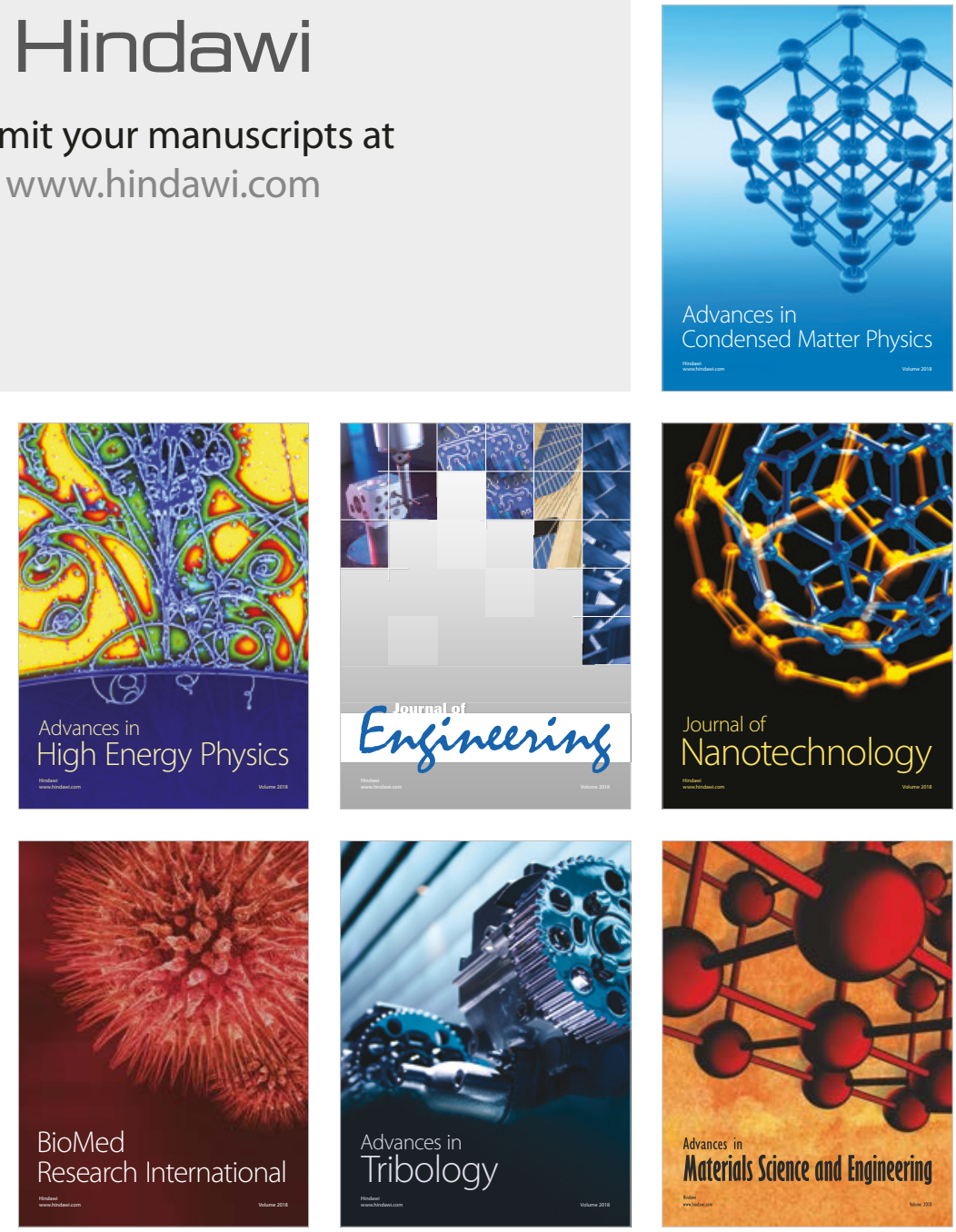